\title{
MUTUAL FUNDS AS INVESTORS OF LARGE POOLS OF MONEY
}

\section{INTRODUCTION}

Professor Robert H. MUndHeIM: Good morning and welcome to the University of Pennsylvania Conference on Mutual Funds.

One of the most striking things about the mutual fund industry is the phenomenal speed with which it has grown. It is its growth in size and maturity which raises questions with respect to the present adequacy of a regulatory framework designed in 1940 to govern a half-billion dollar industry-roughly one-eightieth of the size of the industry today.

The Wharton School Study of Mutual Funds ${ }^{1}$ and the Commission's Report of the Public Policy Implications of Investment Company Growth ${ }^{2}$ have been the major studies which attempt to identify the problems which such growth has created. The material and analysis in these studies will figure prominently in our discussions today and tomorrow.

I am delighted that so many of you have come here, many of you from quite far off places (including one from London), to think for two days about the vital issues which confront the industry. Some concern has been expressed that any discussion of these issues should appropriately be reserved for Congressional hearings on Commissionproposed legislation. ${ }^{3}$ I disagree with those who hold that view. I think that a great deal of benefit can emerge from public discussion and analysis of the issues prior to any Congressional hearings. I think that such discussion should assure Congress of more thoughtful and complete presentations at its hearings. It also gives various people, like yourselves, who are interested in the mutual fund industry an opportunity to learn what the Commission is trying to do, and gives the Commission a further opportunity to understand the impact of some of its proposals.

It is in this spirit of exchange of views and amplification of positions that this Conference was organized. It was not organized to provide an arena for verbal battles about fixed positions.

1 Wharton School of Finance and Commerce, A Study of Mutual Funds, H.R. Rep. No. 2274, 87th Cong., 2d Sess. (1962) [hereinafter cited as Wharton Report].

2 Securities \& Exchange Comm'n, Public Policy Implications of Investment Company Growth, H.R. REP. No. 2337, 89th Cing., 2d Sess. (1966) [hereinafter cited as SEC Mutual Fund Report].

3 The Commission's proposals are found in S. 1659, H.R. 9511, 90th Cong., 1st Sess. (1967). 
I hope that this Conference will serve an educational functionin its broadest sense. In that connection, I want to remind you that each panelist is here in his individual capacity. He does not purport to speak for the organization which employs him. The views he expresses are his own.

In addition, you should bear in mind that the Commission's report has been publicly available for only two months. That is a relatively short time. Consequently, in many areas firm conclusions may not have been reached with respect to the need for changes in the regulatory framework or, if need for change is thought desirable, concrete alternatives to the changes recommended by the Commission may not have been developed yet.

As I indicated before, the Commission's report occupies the center of any discussion of the problems facing the mutual fund industry. I think, therefore, it may be appropriate to begin by asking you, Commissioner Wheat, to tell us how the report came into being.

\section{Background of the SEC's Report}

Commissioner Francis M. Wheat: The program of this Conference, the fact that it could be held at all, testifies to the great advantage of our free society. The beneficial effect of an atmosphere which promotes a free interchange of ideas is no better evidenced than in a situation like the one we have here.

There may be a few differences that will come to light during the Conference, but the three of us here from the Commission hope most of you will look on this as an opportunity to explore, rather than to debate. I am glad to hear from Bob that such is the spirit of this Conference.

We expect, in view of the talent and experience of our fellow panelists, to carry back to Washington some valuable insights. For our part, we will try to explain what lies behind the recommendations in the Commission's report which are relevant to the topics of the Conference. If misconceptions exist regarding many of these recommendations-and I think there are a few-it will be our job to try to clear them up.

With these as our objectives, perhaps you will forgive us if we do not try to answer, toe to toe, all of the arguments against the report's conclusions which our skillful friends in the industry undoubtedly can muster.

And let me add the usual official disclaimer. To the extent that any of us are led to express our own ideas, you must remember that 
our colleagues at the Commission are entitled to regard them as pure heresy.

Most of you are thoroughly familiar with the background of the Commission's report. Perhaps of interest is the fact that it is the outgrowth of the efforts of three groups of people. The Wharton School, which made the basic study, delivered its results to the Commission and to the public in 1962. The Special Study of the Securities Markets, prepared by a group of men whose unique relation to the Commission might be described as within yet apart, covered other aspects of the industry in a portion of its report to the Commission in 1963. The third group consisted of the Commission's own staff. Perhaps the most important observation I could make, however, is that the report is very much the product of a painstaking, conscientious effort by all the Commissioners. It is not simply the product of the staff, given official imprimatur by the Commission.

The Commissioners are men of widely different backgrounds. This made for a good deal of give and take in the long sessions we held to probe and dissect each of the alternative approaches to the problems we examined. Many parts of the report took shape very slowly, with repeated and detailed drafting recommendations from the individual Commissioners. The staff was left to derive small comfort from the fact that Plato, according to the story, rewrote the first paragraph of The Republic twelve times.

\section{The Commission's Objectives}

The report has been given-what should I say?-a varied reception. Some have told us that we did not go far enough. The reaction of some others reminds me of a certain Duke of Cambridge in the eighteenth century, who is alleged to have said: "Any change of any kind at any time for any purpose is to be deplored."

There are some, I am afraid, who may have seriously misconstrued our recommendations. Let me comment briefly on one troublesome misconstruction.

It has been said that the Commission seeks to subject the investment companies to public utility-type rate regulation. Nothing could be further from the fact. As to the management fees charged by the external advisory firms, the public utility concept of fair return on prudent investment would be wholly inapplicable. What the Commission seeks is an appropriate and meaningful standard of fiduciary responsibility in an area where arm's length bargaining over charges is simply not possible. 
On the subject of sales load, the suggestion is that a maximum be fixed, as was done by statute in 1940 for front-end loads. This is hardly rate-making in any commonly understood sense. The reason why this recommendation was made, in lieu of a recommendation that the statute be amended to permit free competition among dealers as to the load charged in connection with the sale of mutual fund shares, will, I'm sure, be the subject of a lively discussion. Let me say, however, that this recommendation and a number of others in the report share a common thread. It is a thread which serves in a broad sense to tie together many of the provisions of the existing securities laws.

Our objective is to keep the securities markets and the choices open to investors as free as possible from potential distortion from any cause. Such distortion can come from lack of available or adequate information about companies whose shares are publicly sold-hence the need for the registration and reporting requirements of the $1933^{4}$ and $1934^{\circ}$ Acts. It can, of course, come from fraud practiced on the investor-hence the anti-fraud provisions. It can arise from market manipulation. And, finally, as the report observes, it can develop when enormous disparities exist in the incentives which salesmen have to sell different kinds of securities.

The ultimate objective of fair and orderly markets for securities which are deserving of public confidence is one, I think, we all share. No one questions the increasing importance of investment companies in the securities markets. Their amazing growth and popularity invited the attention which they are receiving here and elsewhere. I for one look forward with the keenest interest to the proceedings which have begun this morning.

Professor Mundheim: When are these recommendations going to be translated into legislative proposals? When is Congress going to hold hearings on the proposals?

Commissioner Wheat: I can't give you any meaningful guess as to either question. I would hope that there would be hearings later this spring. I think in the relatively near future the Commission will complete its work on a draft bill to the Congress and submit itbut as to any real timetable, I'm afraid I could not give you an answer.

4 Securities Act of 1933, 48 Stat. 74, as amended, 15 U.S.C. \$\$77a-77aa (1964).

5 Securities Exchange Act of 1934, 48 Stat. 881, as amended, 15 U.S.C. §§78a78hh (1964). 


\section{Mutual Fund Influence Over Portfolio Companies- The Mutual Fund as a Shareholder}

Professor Mundheim: In its discussion of the tremendous growth of the mutual fund industry, the Commission also describes and focuses on the rate of growth of individual funds and fund complexes, and contrasts it, interestingly, with the concentration of fund holdings in a relatively small number of stocks. Indeed, although the total assets of the three largest funds more than doubled between 1958 and 1964, the number of stocks carried in their portfolios decreased substantially.

One of the questions raised by the growing size of individual holdings is the extent to which the management of mutual funds has a right or a responsibility to influence the management of its portfolio companies. I was told at a conference held at Duke Law School ${ }^{6}$ two years ago that this question is an academic one. However, it now appears to be raised in a very concrete and urgent way in Senator Sparkman's letter ${ }^{7}$ to the six funds which hold roughly 20 per cent of the stock of MGM, a company currently the subject of a proxy dispute.

Professor Baum has given a great deal of attention to the rights and responsibilities that institutional investors should exercise with respect to their portfolio companies. Some of those thoughts are articulated in his book, The Silent Partners, ${ }^{8}$ which I heartily commend to all of you.

Professor Baum, do you think the Commission gave the problem of investment company control of portfolio companies sufficient attention? Are there any recommendations which you would have made in this area had you written this report?

Professor Daniel J. Baum: The special report on mutual funds comes not from the staff of the Securities and Exchange Commission, but from the Commission itself, a body consisting of five individuals, each with his own values, and his own interpretation of the admittedly complex facts. In such a context the report should not be condemned, but praised. It has both integrity and vigor. Yet this should not deter us from inquiring into the state of the industry and asking the questions Congress intended.

6 Duke UnIVERstry Schoot, of Law, Conference on Securtties Regulation 145 (Mundheim ed. 1965). The remarks were those of Gordon D. Henderson.

7 See Wall Street Journal, January 19, 1967, p. 3, col. 2. Senator Sparkman queried the six about the policy they followed in proxy contests and whether they thought the Senate Banking and Currency Committee should consider legislation covering these situations.

8 Bauni \& Stmes, The Silent Partners: Institutional Investors and CorPORATE CONTROL (1965). 
The report is lacking in the attention given to and the recommendations made concerning the problem of mutual fund control over portfolio companies. Consider some of the facts presented in the report: decision-making in the mutual fund industry is highly concentrated; eight advisory organizations control about half the industry's assets; ${ }^{9}$ moreover, the monies flowing to the funds are invested, it appears, in an ever-decreasing number of issues. ${ }^{10}$ This is nowhere better illustrated than in the aerospace industry. Seventy-eight investment companies, representing about two-thirds of the assets of all investment companies, held more than 10 per cent of the outstanding common stock of five major aerospace organizations. ${ }^{11}$

\section{The Argument That Mutual Funds Are Locked In}

Because of market rigidity brought about by the growth and subsequent concentration of other institutional investors and because of size, the giants of the mutual fund industry find themselves in a position where they can neither buy nor sell as their best business judgment dictates.

Essentially, they are locked into a number of issues. The Commission noted all this in its report, yet recommended no "major new legislation." Rather, the Commission urged that the informational gap be closed "with respect to pension funds and other institutional investors through amendments to existing Federal regulatory statutes and through other appropriate means." 12

I do not believe the Commission's recommendations reflect the conclusions that the facts command. The Commission neglected the opportunity presented to develop a recommendation it made at the time the Investment Company Act of 1940 was first considered:

Investment companies may serve the useful role of representatives of the great number of inarticulate and ineffective individual investors in industrial corporations in which investment companies are also interested. Throughout the course of the existence of such industrial corporations, various problems are presented to their stockholders which require a degree of knowledge of financial and management practices not possessed by the average stockholder. Investment companies by virtue of their research facilities and specialized personnel are not only in a position to adequately appraise these situations but also have the financial means to make their support or opposition effective. These investment com-

9 SEC Mutual Fund Report 48.

10 Id. at 291-98.

11 Id. at 293.

12 Id. at 303 . 
panies can perform the function of sophisticated investors, disassociated from the management of their portfolio companies. They can appraise the activities of the management critically and expertly, and in that manner not only serve their own interests but the interests of the other public stockholders. ${ }^{13}$

\section{Obligations of a "Locked In" Fund}

On two grounds the funds argue against exercising influence over portfolio management. (1) The funds seldom possess sufficient shares individually in any corporation to exercise control. (2) The funds frequently buy management. If they don't like management, they sell. On both points the argument fails. (1) The ability to influence portfolio management is not necessarily related to the vote, although the report was not without examples of funds in de facto control positions. Portfolio management is vulnerable to the influence of a powerful institutional investor because it cherishes the benefits that may come to a corporation from long-term institutional investment. (2) Grant that funds buy management. Are we to assume that on the first mistake by that management the funds will sell? Does portfolio management change character so quickly? Can't the funds take steps to make a good investment better?

How curious is the argument of the funds. It hardly can be harmonized with the statements of some fund managers that there are occasions when fund views are made known to portfolio management. And, more important, the argument certainly cannot be applied to those funds which are locked into portfolio corporations. By definition the realistic option of selling may not be open.

Specific content should be given the term "locked in." For purposes of this discussion it will suffice to say that a fund is locked into a given issue if it cannot sell with relative ease and without substantial loss. To the extent that funds are locked into a portfolio corporation they share a community of interest with all other shareholders of that corporation. In legal contemplation, viewed purely in terms of managing other people's money, the funds should be under an obligation to protect their investment by checking portfolio management.

The suggestion is not radical. Funds already have demonstrated their ability to act. They have challenged a corporate decision to issue nonvoting stock where the result might have been delisting of that corporation's stock. ${ }^{14}$ For a variety of reasons they have raised

13 Id. at 310 .

14 United Funds, Inc. v. Carter Prods., Inc., CCH 1961-64 FED. SEc. L. REP. I 91288 (Baltimore City Cir. Ct. 1963). 
questions about proposed mergers, stock option plans, and pension programs. $^{15}$ And, where given the opportunity afforded by a proxy fight, like that which rocked Montgomery Ward, they have assisted in forming a new management team. ${ }^{16}$

\section{Suggestion for Limiting Mutual Fund Lock-ins}

On fund control over portfolio corporations, alternative recommendations should be considered. If funds are locked into an issue, they should be compelled to exercise their influence over portfolio management for the benefit of all shareholders of the portfolio corporation. If we take the position that funds should not be locked into an issue, that this is not good investment policy, then certain conclusions may follow: perhaps limitations should be imposed on the amount of any single issue that fund complexes, not just individual funds, might acquire. The limitations would relate not to outstanding stock, but rather to trading volume.

The choice of alternatives, in some measure, will be determined by that which will result in the better investment policy. I believe that purchase for long-term holding, as contrasted to purchase for trading, generally is the better investment policy. However, this is a proposition which I understand Dr. Friend will develop.

\section{The Dilemma of the Funds}

Professor MundheIM: Fred, you have been busily scribbling notes. What bothers you about Professor Baum's comments?

MR. FRED E. BRown: I think my problem is that I would like to make a talk in reverse. It seems to me that mutual funds are caught in the middle of a great many things. One of these relates to what we are supposed to do in this great area of influencing management. On the one hand, if we say we will sell if a company in which we have an investment develops problems, we are told that this is bad. We are told that we have a responsibility to hang on and try to influence corporate managers to bring about improvement for the benefit of the investment community at large. On the other hand, we are told that if we try to influence corporate managers, if we try to use the presumed power of our investment holdings, this is bad.

So there is some problem here. I think it would help us all if Dan Baum and others interested in us would devote more time to the definition of this problem, to pinning it down, before attempting

15 See Duke UNIVERsity School of LAw, supra note 6, at 215-17.

16 BAUM \& STILES, supra note 8 , at 69-72. 
to solve it. And I would hope that in the process they would keep in mind our responsibilities to our own stockholders.

\section{Argument That the Funds Are Not Locked In}

Now, there is an assumption in what Dan has said that we can't sell our investment holdings, that we get locked in. I don't believe this assumption holds water. There is an old principle in the financial business that if you put enough commission on a security-and maybe this is what the SEC is saying about mutual funds-you can sell it.

There are methods of doing this. There are methods of handling large blocks of stock. Time after time secondary offerings are made, and successfully made, which exceed the size of the holdings of most, if not all, mutual funds. So I really don't think that being locked in is the problem that Dan and others have suggested it is.

\section{Objections to the Suggestion for Limiting Fund Lock-ins}

Let me turn to the suggestion that the Commission impose limits, related to trading volume, on the amount of stock of any issue which a fund would be allowed to hold. I think such action would place the Commission in the area of management, which so far it wiselyin my opinion-has avoided.

In addition, implementation of such a suggestion raises a number of problems. To take one example, it would be very difficult to determine the trading volume. How do we figure it? Do we take volume on the New York Stock Exchange at any given time in a given stock? The volume traded on the New York Stock Exchange may be only a fraction of the total actually traded. Frank Weeden may be making a large and an active market at that particular time. There might be markets elsewhere. How would we know?

So this is another area where I feel very strongly that we are talking about problems, and trying to cure problems, before we know what the problems are.

Professor Mundheim: Are you also suggesting, Fred, that there are other ways for funds to get locked into investments, and generally, we should look at it as a responsibility of an investment manager not to get into the position where, for one reason or another, it becomes difficult for him to get out?

Mr. BRown: It is a manager's business not to get locked in to the point where he can't get out. We are talking about mutual funds. Mutual funds hold out the right of redemption. How can you operate 
consistently with the right of redemption you have set forth in your prospectus, if you permit yourself to get locked into investments to any material extent? You can't.

I would add one thing. I don't think a loss locks in a mutual fund. Dan referred to getting out without a loss. I don't think this is a significant consideration.

\section{Adequacy of Markets To Handle Fund Portfolio Needs}

\section{Professor Mundheim: Walter?}

Mr. Walter N. Frank: I would like to add a little bit to Fred's comment. I don't want anyone here to feel, because the expression "locked in" has been used, that it is axiomatic, and that it's the gospel truth. I think auction markets and the methods of distribution that have been developed could handle almost any size distribution (even at times when we have to include my competitor, Mr. Frank Weeden).

I remember when the Ford Foundation sold two million shares at one particular time, and I don't believe there is a fund that has a position of two million shares in any issue. I think you should forget the thought that you are locked in because of the inadequacy of markets and the inadequacy of distribution process.

MR. BRown: I don't want to talk too much, but there's one other thing I would like to mention, and that is the ebb and flow of investor sentiment and psychology in the stock market. I'm going back to this idea of limiting fund investments to a percentage of the trading volume.

All of us know that markets change with the times, with conditions, with sentiment and psychology. What may be a good market in one stock under particular conditions may become a relatively poor market in times when the particular stock is out of style or favor. Within the last year the cement stocks have provided an example. For a long, long time you couldn't have given one away. In the last month or two they have done quite well in the market and their trading volume has picked up substantially. We are working on shifting sands and you can't set a sensible percentage limit. You can't be so precise about this business.

Therefore it seems to me that the size of individual mutual fund investments must be a matter of management judgment. That judgment involves the exercise of a great deal of skill and experience in handling blocks of stock and in moving out of securities without interfering with existing markets. 
Professor Mundheim: Frank?

CoMmisstoner Wheat: I have been listening to everything Mr. Brown said and it is comforting. It gives me a chance to add the comment that we thought we were preparing a conservative report. We eschewed recommendations where we didn't think we had a large body of information and a strong basis for them, and in the area that Dan Baum has discussed, we felt that we did not have the kind of data which would be necessary to make any positive recommendation at this time.

We made some careful studies, as those of you who have read the report know. We recognize the fact that when a large fund has to dispose of a large block, it frequently does so in a secondary distribution of the type that Fred mentioned, at a commission charge which may be two, three or four times the normal New York Stock Exchange commission charge. ${ }^{17}$ Perhaps a very small fund would not incur the expense of such a disposition.

On the other hand, comparing the performance of the very large funds and fund complexes with those of the smaller funds that don't have this problem, we did not find any marked or significant disparity. This would tend to indicate that a locked-in situation has produced little serious harm-or any harm, really-to investors as a whole.

Our general philosophy, if I can make a personal comment on it, would be to try to follow the policy of encouraging the development of strong securities markets, allowing maximum freedom in handling portfolio transactions, rather than to try to think in terms of restrictions. In contrast, the commodity exchange has very distinct restrictions which we would like to avoid for the stock market.

It is interesting, however, just to add one final comment. that very recently, within the past six months or a year, there have been two or three new mutual funds which have expressed in their prospectuses the philosophy-as a matter of fact, not just the philosophy but a rigid limitation-that they will not grow beyond $\$ 100$ million. That was the typical figure in at least two of these. The management of these funds must have had some strong reasons for picking that as the maximum to which that fund would be permitted to grow.

So we have some interesting developments on the basis of the free choices by individuals in the fund business.

17 Securities \& Exchange Comm'n, Special Study of Securities Markets, H.R. Doc. No. 95, 88th Cong., Ist Sess., Pt. 2, 844 (1963) [hereinafter cited as SEC Special Study of Markets]. 


\section{Primary Responsibility of Fund Management}

DR. IRWIN FRIEND: I would like to make the general comment that the two positions expressed here are really not at all different philosophically. I gather that both of you feel that the primary responsibility of the mutual fund management is to optimize the interests of their own shareholders, and not to look out for the interests of the stockholders in the portfolio companies. The only difference, it seems, is a factual one as to whether mutual funds are or are not effectively locked in.

If they are locked in-and I don't think that they are to any considerable extent-their obligation would still be to maximize the interests of their own stockholders, rather than of other stockholders in portfolio companies. To the extent that there is any divergence between the two, it seems perfectly clear where the responsibility of fund management lies.

I was interested that no one here-and, I think, wisely, perhapstakes the position sometimes expressed, that, in view of fund size and the impossibility of negotiating at arm's length, the mutual fund management does have a broader responsibility for the other stockholders in portfolio companies.

Professor Mundheim: I thought Dan leaned that way when he said that when a fund is locked in it's got to exercise responsibility not only with respect to its own shareholders, but also with respect to the other shareholders. ${ }^{18}$

DR. FRIEND: But I think he also pointed out that there were coincident interests. I think it would be useful to get his reaction as to what fund management ought to do where the two interests are not coincident.

Professor Baum: I tried to limit my remarks. Funds already are locked into some of the more important issues on the Big Board. To the extent that this is so, the interests of fund shareholders merge with those of the portfolio corporation's shareholders. Fund managers ought to exercise responsibility in relation to the portfolio corporation simply because they have a responsibility to their own shareholders.

However, even where the funds are not locked in, they ought to exercise responsibility and judgment toward the corporations in which

18 See p. 675 supra. 
they hold stock; the funds are in the position, which they widely advertise-at least through their salesmen-of obtaining information concerning the operation of corporations in which they invest. The funds tell us that they speak with management; they obtain opinions from management; they obtain facts. In this regard I'm not talking about the kind necessarily relating to a new ore deposit, but I am talking about the plethora of detail that allow for the exercise of informed judgment, the kind of facts that may not be found in the published journals. Because the funds are in a position to obtain such facts, they should assume some kind of obligation in relationship to other shareholders.

I think that at this point I've moved far away from any community of interest that Fred and I night have had.

\section{Pitfalls in Fund Infuencing of Portfolio Management}

\section{Professor MundheIm: Is that right, Fred?}

MR. BRown: That is exactly right. All of us who manage mutual funds work for the people who own the shares of those mutual funds. Our job is to do a good job for them.

It seems to me that what Dan wants to do is to put us in the position of being second guessers. We're to look over the shoulders of American management and decide whether it is doing the right thing.

Now I happen to think that we are not competent to do that job. I don't believe that we are competent to pass judgment on corporate matters of all kinds. I believe that if we attempt to do this, we will get into the hottest water we have ever been in.

And let me say that there is an occupational hazard in working for mutual funds. In a real sense, we live vicariously. We visit and talk to management. We say: What are your problems? What are you doing about them? How do you do this? How do you do that? And if we are not careful, the first thing we know, we begin to think, despite our inexperience, that we could run a business better than its own executives run it. This is an attitude that we have to watch very carefully, especially in our younger analysts.

If we begin to tell everybody how to run their businesses, I would have some concern for the economy of the country.

Professor BAUM: Bob, may I just put in a very brief, youngish kind of reply? 
I'd like to quote from a statement made by David Rockefeller in 1958.

I might . . draw your attention to one important change in savings that is occurring: namely, the tendency for personal savings to flow more and more through institutions-through insurance companies, pension funds, mutual funds and the like-rather than through individual savings accounts. During the sixties, corporations will find themselves dealing increasingly with these sophisticated investors. Moreover, I suspect that such investors will become more demanding of management as time moves on-that as holdings expand, institutions, as well as individuals, will feel obliged to take more active interest in seeing that corporations do indeed have good managements. This will be true especially if their holdings become so large that they cannot readily or quickly liquidate their investments, as is now their practice when they become dissatisfied with the management of a corporation in which they hold shares. ${ }^{19}$

\section{The Conglomerates}

Professor MUNDHEIM: Before moving more deeply into the question of lock-in, which seems to hold the key to much of our discussion-let me raise an additional problem relating to control of portfolio companies. Do any of you see a problem of a different magnitude when, for example, the investment adviser of a mutual fund with large holdings in a brewing company, is also interested in a maker of barrels used by brewers? I am thinking about the conglomerates. Various kinds of companies are now beginning to have an interest in investment advisers, and in that way may be able to exert some influence over the funds' portfolio companies. These portfolio companies may have some business relations with the company which owns the adviser.

COMMISSIONER WheAt: Well, I suppose if you are speaking to us at the Commission, naturally this and many other things are matters of concern, and probably will continue to be, but we have not to date noticed that this has become a problem which we can put a finger on.

We have, as you all know, some very careful controls in the Investment Company Act on transactions involving a purchase or sale or a loan or similar types of transactions between investment company managers and the investment company, or the affiliates of the investment company; perhaps these controls, which have proved very workable for the last twenty-five years, may be sufficient in this area. ${ }^{20}$

19 BAUM \& STILES, supra note 8 , at 80 .

20 Investment Company Act $\S 17,54$ Stat. 815 (1940), 15 U.S.C. $\S 80 a-17$ (1964). 


\section{The Grant Mutual Fund}

Professor MundHeim: If no one else has a comment on that particular problem, let us turn to the problem of the large fund, because in many ways it poses the problem of portfolio mobility most acutely. Indeed, the Commission's concern in that area was evidenced by its conclusion that "there is no reason to believe that the shareholders of the largest funds would benefit from further growth." 21

I suppose after reading that, Bill Moses, the trustees of M.I.T. and the Board of Directors of M.I.G.S. got together, and they have now put a limit on the size of those funds. ${ }^{22}$

Mr. William B. Moses: That's a fine question to start me off on.

On the contrary, the meetings that we have every week are devoted to thoughts of further growth of both funds and the offering of all the benefits and advantages of size to not only our existing shareholders, but to many more. In fact, Professor Mundheim's question reminds me a little bit of something in the past.

A little over twenty-five years ago I left the confines of Wall Street to join Massachusetts Investors Trust. It had just passed the $\$ 100$ million mark in size, the largest fund in the country, and my friends, in wishing me well, said in awe-stricken tones: Do you realize you are going to the largest fund in the United States? Just as if I were going to work for General Motors or American Telephone or Standard of New Jersey.

I arrived in Boston to find that M.I.T. had just fought the battle of the Investment Act of 1940, in which there was an attempt, or a serious discussion, to put a limit on size. I'm glad to say that wiser counsel prevailed, and that limit was not put on.

But here we are today, twenty-five years later. Time has gone by, and I'm standing here before you trying to defend once again the advantages of size. To me it's ironic, and a little bit sad.

\section{Comparative Performance of Giant Mutual Funds}

The key conclusion that Professor Mundheim referred to is in Chapter VI of the Mutual Fund Report, and I quote it: "There is no reason to believe that the shareholders of the largest funds would benefit from further growth."

Now, how did the Commission arrive at this conclusion?

22 The combined net assets of the Massachusetts Investors group as of June 30 , 1966 were $\$ 3.019$ billion. SEC Mutnal Fund Report 48. 
A study of performance results indicated to them that the largest funds, those in excess of $\$ 1$ billion, did not show the superior performance that would be expected from the various advantages they possessed just by virtue of their size: lower operating expense ratios, lower portfolio turnover, and greater management resources. ${ }^{23}$

The reason for this, the Commission says, is that these advantages apparently-and I stress the word "apparently," because that kind of wording is throughout this chapter, if not throughout the reporthave been offset by a "lack of portfolio mobility and flexibility attributable to their size," that is, attributable to the large size of the holdings of the individual securities. ${ }^{24}$

Therefore, the SEC concludes that since the performance of these funds has not been enhanced by their growth, the funds will not benefit from further growth. And, indeed, the Commission goes on to say that if the growth of the largest funds should continue, the point might be reached where portfolio mobility will be so seriously impaired as to greatly affect the interests of shareholders. And they say this is possible even without any further growth of mutual funds, simply by virtue of the growth of all institutional investors, particularly the pension funds, all of whom are "contributing to the growing problem of portfolio mobility." 25

Let us look at the Commission's basic premise: that the largest funds have not had the superior performance that one would expect from the advantage of size. This conclusion was based on a study of performance for the five- and ten-year periods ending 1965, which indicates that the average performance of the largest funds is no better than the average performance of all funds in similar investmentobjective categories.

Here the Commission has, in my view, fallen into a common and fundamental error, basing a conclusion on the results of a particular and limited period of time. Anyone in our industry who has studied performance knows that varying periods of time with different starting points, will produce widely varying performance results. Let me give you a few examples.

(1) The average performance of the five largest common stock growth income funds (the M.I.T. type), all over $\$ 1$ billion in size at the end of 1965, was superior to the average performance of all funds in the growth income category for the five ten-year periods ending 1965, 1964, 1963, 1962, and 1961.

23 SEC Mutual Fund Report 263.

24 Ibid.

25 Id. at 254-57. 
(2) The average performance of the two largest growth funds substantially exceeded the average performance of all growth funds during these same ten-year periods.

(3) Only the two largest balanced funds performed no better than the average for all balanced funds for the ten years ending 1965 . The inclusion of these two funds, one of the largest and the other the third largest in the entire industry, in the Commission's analysis of big fund performance, was an important factor leading to its conclusion. However, in my opinion, not only do balanced funds represent a minor part of the mutual fund industry, but performance comparisons are less meaningful because of the varying proportions of common stock held in any given period.

Now, let's look at M.I.T. alone, since it is the largest common stock fund. It outperformed the group average in each of these five ten-year periods except the last-the ten years ending 1965. The reasons for that poor performance are clearly discernible and are in no way related to portfolio mobility or flexibility. In addition, in a group of twenty funds considered to be most similar to the Massachusetts Investors Trust in policy and objectives, for each of the past ten years ending in 1965, the Trust ranked in the upper half in all but three, 1959, 1960, and 1965; and again the reasons for poor performance had nothing to do with portfolio mobility and flexibility.

To sum up, the SEC's conclusion that the performance of the largest funds is no better than that of all funds in similar investmentobjective categories is erroneous, as it is based on insufficient and inconclusive data.

\section{Portfolio Mobility and Flexibility}

Now, presumably I could quit right here, having thrown out the SEC's first premise, and we can go home. But the Commission also contends that the mediocre performance, as they see it, of the largest funds is apparently-again, apparently-due to a lack of portfolio mobility and flexibility attributable to their size. Although I have worked for over twenty-five years for the largest common stock fund in the country, I have never found, and do not yet find, any demonstrable correlation between portfolio mobility and flexibility, and performance. The key factors affecting performance are, first and foremost, the investment skill and judgment of the fund managers; second, the investment policy of the fund; third, the relationship of that policy to the economic environment during the period under review; fourth, the industry diversification of the portfolio; and finally, 
of course, the actual selection of the individual securities, particularly the major holdings.

However, let's forget for the moment any further debate about the significance of performance results and the relationship of portfolio flexibility to them, because it is obvious that the Commission and many other observers of the mutual fund industry are concerned about portfolio mobility - about the ability of the large funds to manage their portfolios in any real sense.

This is an area that I can discuss only in the context of our own experience, because, obviously, I'm not familiar with the inner workings of the other large funds.

In the report the SEC states: "The special problems of managing most large funds revolve mainly around the fact that they buy and sell large blocks of securities." 26 Despite the size of the Trust, we have never felt that we had any such problem. With few exceptions, we always have bought freely and sold portfolio securities in the desired amounts, large and small, within acceptable price ranges and reasonable periods of time.

A major factor in our ability to maintain this mobility as we have become larger has been the rapid development of so-called bloc trading techniques, a development which has grown hand-in-hand with the growth of the institutional investor. As a result, contrary to the general impression and the impression of the SEC report, we are more liquid today than we were five years ago.

The Commission goes on to say that large funds frequently have difficulty in acquiring securities they desire at prices close to those prevailing at the time the investment decision was made, and to support this claim they cite a few horrendous examples. In fact, in one example they use the phrase "albeit an extreme one," ${ }^{27}$ which gives me license, perhaps, to use some extreme ones too.

But let's look at the facts from our own experience. Last year, 1966 , out of approximately seventy separate purchases voted by the trustees, about 75 per cent were acquired at an average differential of less than $\$ 2$ a share from the price at the time of the trustees' vote. Where larger spreads did exist, the majority were in our favor. This is what one might expect in a declining market, but in 1965, a year of a rising market, our experience was very similar.

Included in our 1966 purchases were eleven new additions, or new names, ranking in size from $\$ 3$ million to $\$ 14$ million each. The largest of these was 200,000 shares of Trans-World Airlines. The first 100,000 were acquired at an average price of $83 \mathrm{I} / 2$, over a sixteen- 
day period starting July 25. This price compares with a price of 85 at the time of the vote, and a range of 76 to 89 during the whole period.

The second 100,000 shares were purchased over a thirteen-day period starting September 22 at an average price of $56 \mathrm{I} / 8$, which compares with a vote price of 63 , and a range of 52 to 67.

I mention these transactions because $I$ think they are very typical of our operations and experience, and they indicate-to me, anywaythat there is no such problem of mobility and flexibility.

The Commission expressed a similar concern about the ability of the big funds to dispose of large blocs of securities. Again the M.I.T. experience: out of approximately sixty-five votes to sell securities, over 70 per cent were disposed of at an average price within $\$ 2$, plus or minus, of the vote price. The number where a larger differential existed were few and largely favored the fund. Included in these sales were thirteen eliminations ranging all the way from $\$ 1$ million in size to $\$ 14$ million, and the largest one was the sale of 321,000 shares of Goodyear Tire \& Rubber. The major part of this holding, 226,000 shares, was disposed of over a fifteen-day period in April at an average price of 45 , which compares with a vote price of 44 , and a range during this time of 42 to 48 . The balance was sold even more quickly at similar prices-again, a typical and normal experience.

To further support its case, the SEC referred to the increasing use of secondary distribution techniques by large funds and the higher cost of these secondaries, as compared with normal market transactions on the securities exchange. ${ }^{28}$ However, we have seldom found it necessary to resort to the use of secondaries, primarily because the normal channels of distribution are adequate for our purpose. For example, the Trust had only three secondaries in 1966, and none in 1965. In fact, I think the most we have had in any year has been six. We did not have any in 1963 or in 1965.

Perhaps our experience is not typical of other large funds, but it seems to me that the Commission is overlooking the real significance to the stockholder of specific investment transactions such as secondaries or any large bloc trades. The shareholder is interested in how the investment decision ultimately works out, rather than whether the transaction costs $x$ times more than if it had been processed some other way. One example should suffice.

In 1961, the Trust attracted some attention by selling at a price of 40 about $\$ 30$ million of a well-known steel stock through a sec- 
ondary, the largest transaction of its kind up to that time. The Trust netted $\$ 38.50$, the difference representing a cost of 3.75 per cent or about 3.8 times the regular stock exchange commission. However, since 1961, that company drastically reduced its dividend (with a partial restoration recently) and the stock is still selling today for less than what we received five-and-a-half years ago.

\section{Future Prospects for the Giant Fund}

Now, should our stockholders complain about the cost of that transaction? And what does it mean to us as managers? Today, with only twelve stocks out of 106 issues exceeding $\$ 31$ million in size, it indicates to us that under normal market conditions we can dispose of virtually any holding without significant cost or market impact.

To summarize, in our opinion, based primarily on our own experience, the Commission has not justified its conclusion that the shareholders of the largest funds will not benefit from further growth. Portfolio mobility and flexibility does not present the problem envisaged by the Commission. Immobility, to the extent that it may exist, at any given time, is not a factor affecting investment performance, and the Commission's conclusions are not supported by adequate and comprehensive performance data. As a matter of fact, their con. clusion should read: there is no reason to believe that the shareholders of the largest funds will not benefit from further growth.

Now, how will they benefit from further growth? They will continue to have all the benefits of large size. I don't have to spell them out. They are in the report. ${ }^{29}$ But they include lower expense ratio, lower portfolio turnover, and greater management resources, together with satisfactory and, on balance, above average performance, unaffected by any spectre of portfolio immobility and inflexibility.

In closing, I would like to comment briefly on the Commission's fear that growth of all institutional investors, particularly the pension funds, might reach the point where it could very seriously impair the flexibility of the mutual funds. I think all of us, including the Commission, should assume that this growth will continue. We should look on it as a normal, healthy development, in keeping with the growth of the economy, rather than something to be frightened of. Instead of trying to inhibit this growth, as many of the changes asked for in this report would do, instead of talking about the possible need for maximum size limitations, the Commission should devote its energies and talents to assisting the national securities exchanges, the 
institutional investors, and, indeed, the entire financial community to meet and cope successfully with challenges of this growth.

Professor Mundentm: Thank you, Bill.

\section{The Performance Fund}

This picture of the large funds with relatively low turnover having been drawn, it seems appropriate now to hear from Bob Doran who will comment on what has been called the performance fund. Newspaper articles talk about the performance fund as one that tries to capitalize on short-term market trends.

I think Ivest Fund is normally thought of as a performance fund, and I'd like to hear your comments, Bob, on whether or not the performance fund is a different kind of fund. Does it represent a new attitude on the part of investment managers? And perhaps you can also direct your attention to this problem of portfolio mobility.

Mr. Robert Doran: Not only do I represent the small fund, but in the words of Mr. Brown, I'm also a young analyst.

\section{Definition}

I have been asked to address myself to the subject of performance funds: the concepts behind them, their operating procedures, and their impact on our financial system. If my comments help to raise the level of understanding on this very much misunderstood phenomenon, I will have achieved my objective.

Performance literally means the doing of something, fulfilling a wish, accomplishing an objective, attaining a goal. Although it is often assumed to be its own qualifier, implying success, performance must be qualified with such words as "good," "bad," or "indifferent."

To date, the phrase "performance fund" has been used in its most restrictive sense. It is obviously easier to measure the performance of a fund whose objective is limited to, for example, capital appreciation than that of a fund whose objective is general, for example, conservation of capital with reasonable income. As a result, the term "performance fund" has been incorrectly used to categorize a small group of capital appreciation funds whose recent gains in per share value have attracted widespread investor notice and new investor money.

I suggest to you that the term "performance fund" as presently used is a misnomer and needs clarification. In my opinion, a performance fund is any fund which achieves its stated objective and, in competition with funds having truly comparable objectives and policies, achieves relatively superior results over a reasonable period of time. 
Let's examine this definition more closely. It revolves around four basic premises:

First, performance applied to a mutual fund is a measurement of how successfully the fund achieves what it sets out to do.

Second, this measurement is precise. It can be tabulated definitively at any point in time to cover any duration of time.

Third, this measurement is relative. It must be related to the stated goal of the fund. When two or more funds are compared, their goals must be comparable. Although all funds must stand the test of comparison, discretion should be exercised to avoid comparing apples and oranges.

Fourth, performance must be evaluated over a period of time. It should be self-evident that, the longer the time period, the more meaningful the evaluation.

No discussion of performance would be complete without mention of the qualitative aspects of performance, of achievement. Once the quantitative results are tabulated, one might rightfully want to know more about the character of the performance; for instance, how is the record of achievement accomplished? What degree of risk was assumed to achieve the goal? The answers to such questions in no way diminish the quantitative results, but they might help to put these results in somewhat better perspective.

Performance and the awareness of it should not be considered a fad, fashion, or vogue. It pervades not only our industry, but business universally. The pressure to improve performance is a direct result of a quickening pace of competition. As the mutual fund industry becomes increasingly competitive-and of this we can all be certain-better informed investors will increase their demands for excellence. The rewards for superior performance will be those of success. The penalties for inferior performance will be those of failure.

Performance, then, is an integral part of our business. It is basic to our existence, our continuing growth and our ultimate survival. As Thackeray put it, "Next to excellence is the appreciation of it."

\section{Operating Procedures}

Let us turn our attention to a discussion of the operating procedures of performance funds. The methods and policies used at Ivest may or may not be similar to those used at other funds. There- 
fore, I can only speak for our fund, and my comments in no way represent the attitudes or values of our competitors.

The elements of successful fund management can be separated into three groups: First, the organization itself; second, the portfolio policies; and third, the philosophy of management which pervades both.

A contemporary mutual fund organization depends upon management and communications. Management is the heart and soul of any organization. It is imperative that only the most competent minds be hired for analytical and portfolio management work. There is no substitute for investment talent.

These money managers must understand the goal and be properly motivated to obtain it. Since money management is a highly individualistic art, an atmosphere conducive to creativity and individualism must be established.

In conjunction with this, management must be effectively compensated, with significant monetary rewards, but, more importantly, with freedom, authority, and responsibility.

It should be noted that management can reach optimum effectiveness only when equipped with the best tools available. This includes an up-to-date knowledge of the most contemporary methods of both fundamental and technical analysis.

There is a Spanish maxim which states: What the fool does in the end, the wise man does in the beginning. Timing in today's dynamic investment arena is vital; and so we must concern ourselves with the process of communication within our organizations. Information must be gathered, sifted, and evaluated immediately. Particular priority must be given to processing negative information. Delays in time in evaluating such information can be extremely costly. Sources of information must be continually checked, assessed, and updated.

There is a trend toward the creation of total in-house research capability. Such capability reduces the firm's dependence on outside sources and ultimately offers optimum control over investment results.

The time required for the decision-making process must be constantly reduced. If committees prove cumbersome, they must be replaced. The most effective means must be employed to streamline communication and decision making.

The second element of successful fund management relates to the actual portfolio policies practiced by the firm. The variance in the policy views is considerable, but the policies at Ivest are as follows:

First, relative concentration. This results in a sharper focus on companies of particular interest. A policy of selectivity leads to 
greater control over the portfolio and, among other things, helps to avoid overstaying in a deteriorating situation.

Second, relative marketability. A fund must be able to establish and eliminate positions in the shortest possible time period with the least impact on the price of the stock. We at Ivest have always had an interest in the Most Active List, which usually gives a day-to-day closeup of current trends. Looked at in the proper perspective, this can be very revealing.

Third, relative quality. If you can achieve superior performance with well-timed decisions in quality securities, you will have achieved the qualitative performance referred to earlier. This is the ultimate mark of professionalism to which many of us aspire and which very few of us attain.

Fourth, relative activity. We live in a world where change is the one certainty, a world where there is a running historical struggle between the comforts of the status quo and the continuous pressures for change. It is absolutely imperative that management be sensitive to change. In so far as activity reflects this sensitivity for the serious and well-considered efforts of management to attain its objectives for its shareholders, we regard such activity not only as acceptable but as an integral part of our obligation.

Perhaps the words of $T$. H. Huxley best express the attitude of Ivest's management toward activity: "The great end of life is not knowledge, but action."

\section{Philosophy of Management}

The single most important element for successful fund management is the philosophy of management, which concerns the beliefs, concepts, and attitudes of the management group. Time does not permit me to comment on all of these, but no discussion of performance would be complete without the mention of certain fundamental philosophies.

Of paramount importance is the concept of flexibility. The sensitivity to change mentioned earlier is the cornerstone to successful investing. Of equal importance to the performance-oriented investor is a profound belief in innovation. Management must demonstrate the willingness to try the untried, and must continuously develop the most contemporary methods and procedures to do the job.

Something that is very helpful to our group is the recognition that ours is a fallible art. Realistically, we must be prepared to make mistakes, to profit from them, and then to forget them. 
I believe it is safe to say that all performance funds have an understood philosophy of industriousness. Performance can be equated with hard work.

Lastly, we have a fundamental belief in the individual and in the continuity of management. Our policy, reduced to its simplest terms, can be stated in this way: Hire men more intelligent than you are, and then people more intelligent than they.

We will not know the total impact of the increasing performance orientation of our industry on our financial system for some time. Many, many questions might properly be raised. Answers to them at this juncture must be conjecture.

For instance, can we in the fund business anticipate that the individual will be given more freedom and responsibility in decisionmaking? If so, what are the implications for all of us in our continuing search for the best investment talent? Can we look forward to stronger, deeper, and more independent internal research organizations? Will we be forced to utilize new technological innovations to remain competitive? Is it fair to assume that those firms which achieve excellence will some day dominate our business? Is the trend toward the institutionalization of wealth merely in its infant stages?

These are questions that we fund men must at the very least ask, and try to answer.

Will our portfolio policies stress greater or less concentration, higher or lower turnover? It is interesting that in 1962 the turnover rate for open-end funds was 14.7 per cent, and only 10 per cent of the thirty largest common stock funds out-performed the Standard \& Poor's 500. Can we draw any conclusions from the fact that in 1966, when the turnover rose to 29.9 per cent, some 94 per cent out-performed this yardstick? Turnover per se certainly does not create performance, but dare we say it has hurt performance?

Will the awareness of differences in performance among mutual funds affect our nation's banks, with their vast trust departments? Can they train and develop money managers, endow them with the needed spirit of freedom and personal involvement, and motivate them sufficiently? If not, can they maintain their present dominance as managers of retirement trusts? Some banks have already asked themselves these questions. Many others apparently have not.

And the impact on the brokerage community-what ramifications are there for this group? Will today's volume of business lull them into complacency, or will the recent development of certain funds joining regional exchanges jolt them into a new competitive posture? Will they develop the necessary skills in bloc trading which must be 
developed to serve the requirements for the increasingly institutionalized and performance-oriented money? Will the in-house research depth of the funds disrupt growth patterns of the so-called research brokerage firms? If so, how will this affect the rise of new firms in this already crowded area? Brokerage firms should turn the attention of their best analysts to these questions.

If answers to some of these questions asked earlier are conjecture, how can we evaluate all of these in their impact on the securities markets? As events are known faster, interpreted by more capable people, evaluated immediately, and so forth, should we not anticipate that the price pendulum will swing in shorter, more volatile cycles? If so, the main effect of performance funds may prove in the long run to be a stabilizing one, leaving securities markets less sensitive to daily trading and more reflective of long-term economic and international trends.

In conclusion, I find that performance funds are any funds which are obtaining their objectives, be they capital growth, preservation, or current income. It is evident that operating procedures of contemporary managers, though they vary considerably, are undergoing rapid change. I have been fairly specific about the procedures our management group uses to achieve its goal, without in any way implying that these are procedures others should adopt.

And, finally, I believe that performance and the great emphasis on performance stems from more active competition for increasingly knowledgeable investor money. A combination of investor demand for excellence on the one hand and management's response by improving performance on the other would and will result in enhanced shareholder benefits. Ultimately, the term "performance fund" will have no meaning, because there simply won't be any other kind.

Professor Mundenim: I am very interested in the relative precision of your definition of "performance," Bob, because it suggests to me that perhaps we can begin to identify the categories of funds more precisely, measure their performance, and then perhaps the SEC can make those results available, so that the investor can very clearly and sharply differentiate between funds and know which one to buy and where he gets the most for his money. Is that what you were leading up to?

MR. DoRAN: I didn't think I was suggesting quite that, but it would be good for investment objectives to be defined as precisely as possible. You might properly address that question to the gentlemen from the SEC. 
Professor Mundereim: I thought they'd probably want to hire you as a consultant, notwithstanding.

Frank, did you want to comment on that?

Commissioner WheAT: Bob said he thought of addressing that to me, and I said, "Please don't!"

\section{Correlation of Portfolio Turnover and Performance}

Dr. FrIEND: I have one question of Mr. Doran, and a comment on Mr. Moses' statement. Maybe I ought to take the question first.

What was that statement about the performance of mutual funds in 1966 ?

Mr. DoRAN: It was the turnover rate-I don't have the table right in front of me-but with a turnover rate of approximately 14.7 per cent in 1962, only 10 per cent of the thirty largest common stock funds out-performed the Standard \& Poor's 500; and then in 1966, with a turnover rate of 29.9 per cent, 94 per cent of those same thirty funds had out-performed the same Standard \& Poor's 500.

DR. FRIEND: Don't you have a very pronounced bias in the direction of your results? You take a year like 1962, where the market was extremely weak. Your funds flow in, and as a result you have cash, which obviously does much better in a declining market. In 1966 you have the same result, but, I suppose, vastly intensified by your much greater inflow.

Mr. Doran: Actually, the 1962 market and the 1966 market were not all that different. I think both periods showed a definite trend maintaining the increase in the turnover percentages that have been increasing year by year; and also there was an accompanying increase in the percentage of these thirty funds that out-performed the Standard \& Poor's. But I felt that 1966 and 1962 were fairly similar kinds of markets. As a matter of fact, I know I felt they looked the same to me. I didn't enjoy either one of them.

Dr. FrIEND: I thought the 1966 market was one where you had a vastly greater inflow of new money into the funds, as compared with 1962. This may explain the results to some extent. Also, I suppose even common stock funds are not fully invested in common stock equities.

MR. Doran: Well, they vary. Usually they are not 100 per cent.

Dr. FRIEND: I must confess that there are two things that bother me about your remarks. One is the statement, which I had not heard 
before, that the common stock funds in 1966 had so greatly outperformed the market. That bothered me a little bit more than the turnover implication in your remarks.

I think we have to make two kinds of adjustments: first, for that proportion of your portfolio which is not in common stocks, and second, for the lag in the inflow of your funds, in this case in a declining market. In the studies that we carried out, we generally found that all funds, including common stock funds, tended to do better than the market when the market was going down, and tended to do worse than the market when the market was going up.

Mr. Doran: Of course, in both of these years you had a little bit of everything. You had periods when nothing was happening. You had periods of sharp decline. You had periods of sharp rally. And for the most part, when we are talking about the thirty largest common stock funds, for all intents and purposes we are talking about an average of 95 plus per cent invested positions in common stocks, and I think it is valid to use those.

As far as new inflow of money is concerned, you know, you have to decide what to do with that money, and I would say that the inflow into these thirty funds was handled very differently. Some funds probably kept investing on the way down all the time; others may have waited and then invested the accumulated cash within a short period of time. I don't know. But I'm not sure that's a relevant factor either.

Dr. FrIEND: However, the Wharton School's Study of Mutual Funds indicated that for the period 1953-58, mutual funds, as compared to the market, did relatively better in periods of declining prices than they did in periods of rising prices. ${ }^{30}$ Now, I'm not in a position to say what has happened since that time. You may have data which I don't have.

\section{Comparative Performance of Giant Mutual Funds}

There is one issue raised by Mr. Moses, which I would also like to comment on. He presented some data indicating that the larger funds did better than the market as a whole, which presumably means better than other funds as well. I'm not in a position to question the data, since I haven't seen them, but I must say that it is inconsistent with some data which have been published, covering not quite as long a time period, which seems to show quite different results. And 
since these results have been published, I would like to refer you to them.

The first was the analysis of performance over the 1953-58 period included in the Mutual Fund Study by the Wharton School. Relating performance to size of fund, we found a sort of inverted U-shape type of effect as you went up in size. Initially, performance seemed to be somewhat better; then as you kept going up, performance turned worse, though the largest funds still did, as I recall, somewhat better than the very smallest funds. ${ }^{31}$

I might add that we also did this for common stock funds separately, so that's not the issue.

Three qualifications should be pointed out. First, it is not clear that the differences are statistically significant. Second, once you adjust the differences in portfolio risk, you eliminate a high proportion of these differences, particularly as I recall, the differences between the medium and the larger size funds. Then, finally, another possible explanation for this rather surprising finding-namely, that performance-wise the largest funds did not do better over this period than the medium size funds-might reflect the lack of flexibility of such funds.

By lack of flexibility, we did not mean-as Mr. Moses seems to feel the SEC report meant-that they couldn't dispose of large holdings. We meant, first, that the bargain has to be very big to be profitable for a large fund; second, something which is a bargain for one thousand shares may not be a bargain if you have to buy 100,000 shares. The price can very well be driven up in the process. ${ }^{32}$

Let me say that we were not sure that lack of flexibility was an important factor. Interestingly enough, initially, we got the hypothesis from some friends in Wall Street.

Now in terms of additional studies, a colleague of mine, Professor Vickers, and I published an article in the Journal of Finance about a year ago which carried some of our earlier results to the end of 1963 on a much less comprehensive basis. Here, we found that the largest funds had a lower average return than the smallest funds, but, at least to some extent, this may have reflected less risk in the portfolio of the largest funds. ${ }^{33}$ We didn't particularly distinguish the largest five funds. We had all size groups represented. Thus, for the 1953-63 period there are published results not yet controverted as to their factual accuracy which seem to be a little inconsistent with the findings

31 Id. at 309.

32 Friend, Romance vs. Statistics in the Stock Market, AmErIcan Statistical Association 1964 Proceedings of the Business and Economic Statistics Section $178,183$.

33 Friend \& Vickers, Portfolio Selection and Investment Performance, 20 J. FINANCE 391, 401, 408 (1965) [hereinafter cited as Friend \& Vickers]. 
reported here by Mr. Moses. Now, it may very well be that something has happened since 1963 which changes the picture, in which case I would say it's a rather short time to come to any very definite conclusions.

So that I don't end up on an unnecessarily controversial note, I would like to point out that neither the Wharton School report nor the SEC study, as I interpret it, are recommending any legislation to limit the size of mutual funds.

\section{Professor Mundheim: Dan?}

Professor BAUM: In this regard I would like to make two points. One is about the SEC's report itself.

It's a report that attempts to deal with-let us use this term loosely-wrongs as they have been found to exist. It spots certain danger signs. Yet the report says: Let's wait. Let's wait and see whether these danger signs ripen into a "wrong," and then we'll deal with them. We'll come forward with recommendations at that time. This is an interesting attitude. From my point of view, it is a most conservative attitude. It's an attitude that doesn't attempt to take prophylactic action. And in this regard I think the report is deficient.

Let me make a point about fund flexibility and mobility. The report is directed toward mutual funds; and yet in a very real way, it's very difficult to talk about mutual funds without talking about all other institutional investors. Institutional investors are highly concentrated. The report tells us that eight advisory organizations control about half of the assets of the mutual fund industry. ${ }^{34}$ The report also tells us, I believe, that twenty banks control approximately half of all noninsured private pension funds. ${ }^{\mathbf{3 5}}$ To the extent that this is true, to the extent that there is an institutionalization of the market, to the extent that the floating supply of stock is sponged up by these institutions, there must be a problem for institutional investors in getting in and out of particular stocks, despite the examples given by Mr. Moses.

Now, the point might very well be that they shouldn't get in and out; that once they buy in, to a greater or lesser extent, they ought to stay in for long-term investment.

\section{Application of Performance Fund Principles to the Giant Fund}

Professor Mundheim: Let me take your comment, Dan, and use it as a basis for a question to Bob Doran. When you talked about relative concentration, selectivity of stocks, relative marketability

34 SEC Mutual Fund Report 301.

35 Ibid. 
and sensitivity to change as guiding principles of your investment policy, you were talking from the vantage point of a $\$ 60$ million fund. What about those principles when applied to a billion-dollar or $\$ 2$ billion fund? Will they still work? Can the huge funds do the things which you suggest a good mutual fund management ought to be able to do today?

Mr. Doran: Well, Bob, I broke down my discussion about procedures into three segments; one related to organization, another related to the actual policy practiced by the fund, and the third related to philosophical elements.

Regardless of size, our management would have the same basic philosophical approach toward money management; we will have the same attitudes and values that we have built up about organization, specifically, that you have got to have good people, that you have got to have smooth communications and so forth. In the portfolio policy area, the key word-and I used it for each one of the four points that I explained-is the word "relative": relative concentration, relative marketability, relative activity and relative size, all relative to the position of competitors with comparable size and so forth.

I'm very tempted, frankly, to answer a very serious question with one word, by merely saying: relatively. Yes, we would expect to use very similar policies to those we use today, even if Ivest Fund were a billion dollar fund. I think it would be naïve to suggest that there wouldn't be some change in the actual procedures that we follow; but if you bear in mind the word "relative," I think we should pursue our present policies regardless of our size.

Professor Mundeeim: I thought that was precisely Dan's point-it becomes relatively more difficult to operate as the funds get larger.

Another way to get at the question of portfolio mobility is to ask: What can the markets handle? Walter Frank is a man who handles a lot of these institutional transactions. Walter, can you talk a little bit about how the exchange market has geared itself to handle the demands which institutional trading makes, and perhaps comment on the strains which we always hear are being placed on the auction market by these institutional developments.

The Exchange Market and the Institumional Transaction

MR. Frank : I was happy to learn at the beginning of this session that each one is here as an individual, and that I'm not here as an official of the Exchange, that I'm here as an individual specialist. 
Some years ago I don't think a specialist was ever invited anywhere. I think we have come a long way.

The development and growth of mutual funds has certainly had an impact on our markets. In the broad, over-all appraisal of market activity and the funds' participation in that activity, it is reasonable to conclude that the infusion of nearly $\$ 40$ billion into the securities market has had an effect on prices. The presence of this tremendous amount of capital seeking employment has most likely forced investors of all types to set standards for share ownership that are somewhat different than might be set if these $\$ 40$ billion were not present in the market; but it is impossible to determine the exact degree of impact or percentage difference in price structure caused by these funds, and I see nothing detrimental in their presence. On the other hand, I feel very strongly that they have had an over-all beneficial effect on our market by bringing to it additional liquidity and strength.

\section{Dramatic Examples of Portfolio Liquidations and Acquisitions}

In the long run the impact of fund presence should not pose insoluable problems. However, there have been many comments offered as to short-term or immediate impact of sizable fund acquisition or liquidation. Instances of large, quickly developed and quickly completed programs of liquidation which have been dramatic and exciting, forcing monetary price changes of 5 to 15 per cent, have caused great concern among some critics. But let us examine a few of these instances and study their effect.

I made a few notes on some of the more exciting transactions that have occurred in the recent twelve months. I think of an instance where a fund entered the market in Motorola when it closed at 184, and created enough selling pressure so that it opened at 175 , down some 5 per cent. Thereafter it quickly went down to 159 .

I recall another experience with Motorola where the stock had closed at 134, and late in the afternoon pressure generated by two funds contributed to the decline to 119 .

I remember another instance involving Xerox, where funds entered the market with what was about 100,000 shares of stock when it was selling at 210 , and caused a momentary suspension in trading. When trade reopened, the price was 201 , down some 5 per cent.

Finally, I recall a recent occurrence where a bloc of 300,000 shares of Montgomery Ward was sold at $191 / 2$, previous price activity having been around the $21 \mathrm{I} / 2$ or 22 level; that represented a 10 or 12 per cent change. In another case over half a million shares of Monsanto were liquidated at a price of 37 , when previous activity had the stock in the 41 or 42 range. 
Well, these are dramatic. They are exciting. They can be upsetting to some people. But to suggest that the fund shareholders were damaged is to offer an opinion without complete examination of the facts. We must think of the end results of these transactions.

I'm certain that the funds which chose to participate in any of these liquidations had sound reasons for their decisions. It's possible that they had immediate use for the funds in other investments which seemed more attractive than the one which they were willing to sell at a 10 per cent discount.

As far as the impact of the decline on other public shareholdersand I have got to think of the market place for all investors-it had little or no impact on anyone who wished to sell shares. Those who wished to buy were offered an opportunity to do so at a price substantially below the previous price level of recent activity. Forty years ago, such a decline might have had a great impact on those who wished to sell. In those days we had margin accounts in which the customers carried a lot of stock on very little margin, and an abrupt change in price might have precipitated selling from that type of account. Since that situation no longer exists, the risk of forcing liquidation by dramatic price movement is no longer with us.

I want to speak about the other side too, because there has been a comment about the problem of acquisition. I recall a time when a fund came in and wanted to know where they could buy 25,000 shares of Litton. The price of the stock was $91 \mathrm{x} / 2$. They completed their purchase at $94 \mathrm{I} / 2$, thus paying a 4 or 5 per cent premium for the acquisition. They later sold at well above a hundred.

I also remember the time when a fund went into Xerox while it was selling at $\$ 250$ a share. Their tremendous demand forced the price of the stock up some 10 or 12 per cent, to a completion of the order at $\$ 280$. At the time it seemed like a rather strong, vigorous move, and it seemed extreme to pay that much extra. That same fund was party to a transaction later at 201, which after adjustment for splits, was the equivalent of $\$ 1,005$ a share.

So I want to make sure you understand that liquidation at a price removed from recent price activity, or acquisition at a price removed from previous price activity, can very well be a sound investment decision and certainly can be very rewarding to those who are involved.

These transactions were all in the auction market, but in addition to the auction market we have established procedures for bloc distributions. The most popular ones are secondary distributions and exchange distributions, and through them we think we have provided 
vehicles for liquidations that would have a minimal effect on the price structure of the security.

So I welcome the mutual funds' participation in our market place, and I look forward to many years of their active participation and impact. At the risk of being coupled with Frank Wheat's Duke of Cambridge, ${ }^{36}$ I would say that I see no industry problems ahead that cannot be resolved without changes in our market procedures. I'm certain that fund programs of acquisition and liquidation can be and will be properly taken care of.

Professor Mundheim: You say, "without changes in our market procedures." What changes in market procedures do you have in mind?

MR. FRANK: The changes in market procedures? I was referring to the suggestions that there might be limitations on acquisitions or liquidations by funds or possible price limits such as have been instituted in the commodities markets. I wasn't speaking to specific recommendations, but to the vague suggestion that because of the size of fund participation in the market, some type of regulation should be developed.

\section{The Third Market and the Institutional Transaction}

Professor Mundherm: To complete the picture of the ability of the markets to handle institutional transactions, we ought to talk a little bit about the Third Market and the contributions it makes.

MR. FRANK WEEDEN: I pricked up my ears when I heard "Third Market." What little success our firm has had is probably due to the fact that we have no opinions at all. And this is the last place I'd want to get out of character in that respect.

The Third Market, as I conceive it, is designed to move securities very efficiently from one customer to another, provided that the customer knows what he wants to do and doesn't need any help in making up his mind. That is only part of the service that the Stock Exchange members perform. We do various types of business with professional customers. We have no individual business, and, as I understand it, no one else in the Third Market is interested in the public or individual business, but only the institutional business. 
The institutional investors are only a part of the total stock market. The public make up maybe two-thirds and the institutions about one-third. But, the institutionalization of the market is certainly in progress.

We have various types of markets. We have markets where there are adjustments from one industry to another. One mutual fund sells, and it's divided up among a number of other institutions, such as bank trust funds, pension funds and other similar accounts. That's not very much of a problem. But I have seen some markets where all the professionals want to sit on the sidelines or all want to sell at the same time. Then somebody has to unload all of those stocks on the public, and we may have pretty violent fluctuations in the market. Now, keeping in character, I don't want to say that fluctuations are good or bad, or give an opinion about the desirability of stabilizing the market. My point is that if all institutional investors arrive at the same opinion, you have a serious problem. It's different when one institution is buying steels and another selling them.

I was interested especially in some of the comments that have been made during the day. I marked down on a piece of paper here "locked in," and have my own opinion on it. My friend to the left, Mr. Doran, wrote "true" and a question mark. I interpret that to mean that he didn't think the funds are locked in, except in the very unusual case where they bought a stock that they usually don't buy. I don't think this is a problem at the present time, and I don't see it arising in the immediate future.

However, I think I might differ a little with $\mathrm{Mr}$. Moses, who gave, to me at least, the impression that he could get more for a big bloc than he could for a small bloc. I'm not inclined to agree with that. I think that if you have 100,000 shares of stock to sell, you have to take a discount from the current market price, and I think it usually varies from a point to a point and a half. If you have 25,000 shares, you may have to shave the price three-quarters of a point, possibly a full point. If you have 5,000 shares, it can probably be negotiated at just under the last sale-maybe a little bit more.

There is another point involved here that I think we should keep in mind. If one fund is selling 100,000 shares of stock, and they reduce the price two points, it gives another fund a chance to buy that stock two points under the market. Afterwards the purchaser can say: "Well, I bought 100,000 shares of stock, and I beat the market." But he had to wait until somebody took the initiative on the other side of the picture.

If somebody is buying stock, it gives the seller who is attracted by the distortion in the buying order an opportunity to come in and 
unload a little bit higher; that's probably where Mr. Moses came in and got an extra good price.

That's the way the ball bounces. But I would say, as a general rule, you have to pay a little bit more to buy a big bloc, or take a little more loss to sell one, than you would for a small amount.

I think that Mr. Frank and I met for the first time today, and we decided that we were going to be very good friends, and that we weren't going to get our necks out, or get into any fights with each other. He is primarily in the auction market, but he did say that they also had up their sleeve, if necessary, a negotiated market. Our market is all negotiated, and we don't have an auction market up our sleeve at all.

Mr. FranK: Seats are available for $\$ 230,000$.

MR. WEEDEN : I think on that I will withdraw, and think about it.

I don't think we are at the point where at the present time the mutual funds really have any great trouble in moving their portfolios and I don't think they are going to for a little while. But it's like the story we have out in California: what's going to happen to the people on relief when the last taxpayer dies?

If the market becomes 100 per cent institutionalized, and there is no public any more, then we may have some different problems.

\section{An Economist's Viewroint of the Institutionalization OF THE MARKET}

Professor Mundheim: A number of panelists seem to foresee more fluctuations in market prices-and more rapid fluctuations. Irwin, from your point of view as an economist, will this disturb the efficiency of the market?

Dr. Friend: Bob, I think I will address myself to a little wider perspective than that, but I will answer your question in the course of my comments.

\section{Mutual Fund Impact on Stock Prices}

Generally I'm in accord with the SEC's conclusions in the part of the report dealing with mutual fund impact on stock prices. Specifically, I agree that (1) "the evidence available at this time with respect to the consequences of the institutionalization of the investment process does not point to a need for major new legislation"; (2) there is a need for a "re-examination of existing market mechanisms and rules necessitated by these changes"; and (3) these changes require "fuller data concerning the security holdings and trading patterns of 
institutional investors than has heretofore been available," with the gap in such data greatest for pension funds. ${ }^{37}$

The Commission does not take any position on the economic implications of the long-term upward pressure on stock prices exerted by mutual funds and other institutional investors over the post-war period, or on the stabilizing or destabilizing implications of their intermediate-term trading activity. My own view is that the long-term upward pressure on stock prices probably has been socially desirable, tending to eliminate some of the substantial disparity between long-run returns on stock and fixed interest bearing obligations, and that on the whole mutual funds have not added significantly to intermediateterm instability of the market.

\section{The Problem of Mass Redemptions}

The Commission's concern with the danger of mass redemption of fund shares in a sharp market decline seems to me to have relatively little basis. Such redemption not only did not occur during the 1962 or 1966 declines, but seems inconsistent with the historical trading pattern of small investors. I think many of us, including some of our friends on Wall Street, have a rather erroneous view of what the small investor is like. If we look either at the odd lot trading balances since the turn of the century or at the net purchase balances of investment company investors since the 'twenties, there is an indication that this group is perhaps the most stabilizing in the market, in the sense that they are more inclined to purchase than to sell in periods of market weakness. This pattern might be reversed if investors who can illafford equity investments are persuaded by uninhibited industry selling practices to make mass purchases of mutual fund shares. I trust that this is not a real danger at the present juncture.

\section{Mutual Fund Impact on Stock Price Fluctuations}

The Commission's main concern in this part of the report is indicated by these excerpts:

To the extent that irregular and relatively infrequent transactions in sizable blocs of securities by large institutional investors become more significant and orders from small investors become less significant, the markets for individual securities become more susceptible to wide and erratic price fluctuations. . . . In some respects the market impact of mutual fund activity is even more significant than that of other institutional investors because mutual funds have higher portfolio turnover rates than other institutional investors and because much of the capital of the funds comes to them from people who, but for the funds, would have invested in 
securities directly for their own accounts. Hence the growth of the funds tends to substitute the decisions of a few professional managers with respect to massive blocs of securities for the decisions of large numbers of individual investors. ${ }^{38}$

The Commission does not adduce any evidence to indicate either that the markets for individual securities have in fact become more volatile, or even if they have, that this is undesirable in the sense of increasing disparities between market price and intrinsic value. It is not clear, for example, that a market which is subject to greater shortrun fluctuations as a result of response to an improved flow of information is worse than a less informed market which is more stable in the short run. Nor is it clear that the market which is the ultimate in stability in the long run as well as short run is to be preferred to a more volatile market which more accurately anticipates the future earnings flow.

Similarly, it is not at all clear that the substitution of the decision of a relatively small number of professional advisers for a larger number of individual investors is undesirable from the viewpoint of optimal markets. Hopefully, the Commission will explore further both the statistical facts and their economic implications.

\section{The Growing Importance of the Nonauction Market}

In this connection, the Commission seems to recognize that a nonauction market may be preferable to an auction market for the disposition of large blocs of securities, and that it is more important to remove institutional restrictions on effective competition in these markets than to channel activity to a particular market. Large blocs might flow to the "Third Market" or other "over-the-counter" markets basically for two reasons: the institutionally prescribed absence of quantity discounts on exchanges, or the intrinsically greater efficiency of the nonauction markets for such transactions. ${ }^{39}$ To the extent that this development reflects the first influence, hopefully competitive forces, aided and abetted by the Commission if necessary, will remove it. To the extent that it reflects the second influence, the development is a healthy one.

There are, of course, certain dangers associated with an increased flow of transactions to over-the-counter markets, but these, it seems to me, can largely be avoided by improving the information flow on transactions in such markets.

\section{The Implications of Fund Portfolio Turnover}

Finally, it might be pointed out that the SEC's report devotes less attention than might have been warranted to the problem of sub- 
stantially increased fund portfolio turnover rates. Portfolio turnover in mutual funds has increased greatly, and in the first three quarters of 1966, amounted to close to twice the nonmember turnover in the market as a whole even if the fund turnover is adjusted, as it should be, for the net sale of fund shares. Such adjusted fund turnover is about four times the estimated stock turnover rate of pension funds (a group of institutional investors with which the mutual funds might be compared) and roughly three times the stock turnover rate for odd-lot public investors (the group in the market most comparable to the purchasers of mutual fund shares).

There is evidence, both in the Wharton School Study of Mutual Funds and in a recent paper in the Journal of Finance by Douglas Vickers and myself, that there is no significant correlation between fund turnover and performance. The Friend-Vickers paper indicates that in the brief period tested, even in the absence of turnover costs, funds as a whole would have done fully as well if they had held onto the stocks they sold as they did by turning over their portfolios. ${ }^{40}$ Moreover, turnover is not costless, since it amounts to not quite one per cent of the value of transactions.

It has been asserted and there is evidence that at least in the past couple of years-a period not covered by the Wharton School Study or by the Friend-Vickers paper-a number of mutual funds have been more successful in carrying on concentrated purchases of selected securities which they sell once the market has responded appropriately. There is, to my knowledge, no relevant published evidence for the industry as a whole. The evidence given this morning is what I would call ad hoc empiricism. However, the Friend-Vickers paper does show that for the three years tested-1958, 1959 and 1962-in one year, 1958, stock purchased by mutual funds did behave somewhat better than other stocks; but it is interesting to note that in subsequent years such stocks behaved worse than the market, so that by 1963 , the 1958 mutual fund favorites had not performed as well as the market as a whole. ${ }^{41}$ The evidence is quite tenuous, but it could be argued that the activity of mutual funds, plus some kind of follow-the-leader market vogue, might have been responsible for pushing the price of favored stocks to a higher than warranted level.

In any case, it is clear that there is no published evidence that high portfolio turnover has paid off for the mutual fund shareholders. There is some evidence that the shareholders may have suffered to a minor extent, but this evidence is not at all convincing. However, 
in view of the major potential conflicts of interest between shareholder and management interests associated with fund turnover, the question may legitimately be raised whether the current trend to higher turnover ratios can be justified.

It is admittedly difficult to see what the SEC can or should do to curtail turnover without interfering with legitimate management prerogatives. Perhaps a minimal step would be to initiate fuller disclosure in this area, so that fund holders are informed of the fund turnover ratio in contrast with selected norms, and informed of the subsequent relative performance of the issues sold and purchased.

\section{Performance Comparison of Mutual Funds and Pension Funds}

Professor Mundheim: There are a lot of points in that talk. Which one of you wants to talk to them first? Bob?

Mr. Doran: One specific thing was comparing the activities of mutual funds with the activities of pension funds, and the implication was that turnover was some four times that of the pension funds.

Can I raise a very naive question: to what extent does the low turnover in pension funds reflect the-well, how can I describe itthe inactivity of managment people who have control over these assets?

For instance, it would occur to me that with the freedom from tax burden enjoyed by pension funds, their turnover ought to be considerably higher than that of mutual funds. In other words, to what extent do your figures merely reflect the fact that pension funds have been very badly managed?

DR. FRIEND: First of all, let me be the first to bemoan the fact that we don't have adequate data on the performance of pension funds. I might add that there is a Ph.D. dissertation covering either six or seven pension funds, a pathetically small number, which suggests that this group-the only group that could be handled this way-did precisely the same as the stock market average; but this is the only evidence that I know of. ${ }^{42}$

In this connection I might comment on one question submitted from the floor. It reads: "A recent story in The New York Times quoted a leading actuary of New York in connection with pension fund investment considerations for the Air Line Pilots Association. The conclusion of the actuary was that of approximately 20 bank- and insurance company-managed pension funds studied over a long period of time, only two of these bank- and insurance company-managed

42 Deitz, Evaluating the Investment Performance of Non-Insured Pension Funds, 1965 (unpublished dissertation in Columbia University Library). 
funds did as well as M.I.T. or the Dow Jones Industrial Averages. What are your comments?"

Now, this is a larger sample than the one available in the Ph.D. study. My guess would be that they are comparing the performance of the pension funds as a whole, including the bond part of their portfolio, which typically may be about 50 per cent of the total portfolio, with the performance of a stock fund and a stock average. If this in fact was done, it produces an inappropriate measure. Under such an approach, you inevitably find that the institutions involved did less well than the stock market averages in a period of rapidly rising stock prices.

I might note that the Wharton School Study of Mutual Funds, which for this purpose covered only the period 1953-1958, revealed that only 13 per cent of the mutual funds did better than the averages if you did not adjust for the composition of the portfolio. ${ }^{43}$ Many of these would be common stock funds, so it's not at all surprising to find only 10 per cent of the pension funds did better, when you make no such adjustment, particularly since you have relatively few pure common stock pension funds.

\section{Correlation of Portfolio Turnover and Performance}

To turn back to Mr. Doran, I am not against portfolio turnover if it has a payoff. I'm simply saying that the evidence-what I would call research type of evidence-so far does not indicate a payoff. When you take each individual fund, look at its portfolio turnover over the period 1953-63, and compute the correlation between turnover and performance, there is no indication of payoff in this data.

And then, finally, as I pointed out, in the very limited experiment which we carried out in the article I referred to earlier, we got the rather amusing result that the stocks sold did slightly better than the stocks purchased. Now, I'll admit that this last experiment covers all of one year, which is a pathetically small time interval.

You may recall that the one recommendation that I made was simply further disclosure in this area, and I'm perfectly happy to have funds churn-and I use the word in no invidious sense-if there is a payoff.

\section{Relation Between Exchange Market and Third Market}

Professor Munderem: Because Walter has a train to catch, can I let Walter make a comment now?

Mr. Frank: I decided that I would take the minutes left before I have to leave, and then no one can rebut anything I say right now. 
I'm not in the fund business, so I may not have the same bias that others might be charged with, but I have a particular problem with accepting statistical data. To me it's after the fact. It's filed under "S"-should have done. I think it's so easy to examine any performance in life, whether it has to do with mutual fund turnover activity or any other type of activity, and say after it's all over: it would have been better if you had done something else.

I think to base your opinion on what would have been is a very, very poor base from which to start, and I think that you have to realize that turnover is a management decision, and there is no assurance of success. At the moment you make the decision, it's a management decision all the way, and to sit and second-guess those who have the responsibility, I think is unwise.

Dr. Friend also mentioned the use of the Third Market. Here I have a bias, but I won't push it at the moment. I think if there ever were one central market for all securities transactions, it would have to be the best; but to suggest that you ought to lean toward one market or the other, because you think it might generally be better, is a poor approach. As much as I compete with the Third Market, I would suggest that when the Third Market offers a better vehicle for your acquisition and liquidation, use it; but don't broadly generalize, and suggest that you should go to one all the time or the other all the time, or that institutions should lean one way or the other. I think that generalizations, including this one, are false.

\section{The Spectre of Mass Redemptions}

Mass redemptions and the problems created thereby have been a major fear for all of us in the securities business for many, many years. I think the only thing that could cause mass redemptions is something that hasn't occurred since 1930, 1931, and 1932. I don't think the investor, small or large, can depend on his own judgment of security value when he's faced with serious crises in his own financial position; that the little man who is out of work and has to sell whatever he has in order to raise funds to live doesn't approach his problem from the point of view of the sound investor. That's the only threat I see in mass redemptions. I hope the day of mass redemptions never comes, but I have great faith that if it does come, we'll be able to survive and come out in fine fashion.

Dr. FRIEND: I would prefer to answer before he leaves.

Mr. FraNk: That's where we differ.

DR. FRIEND: First, let me say that I'm glad to hear that turnover is one of the areas where Mr. Frank does not have any bias. 
Turning to his subsequent comments, I really didn't understand his first and apparently major point, that it is not desirable to look at a situation retrospectively. You know, there is a saying that people who can't learn from history probably can't learn at all. I don't know exactly how you do learn, except from precisely the kind of retrospective study that we at the Wharton School made, and that the Commission has attempted to make.

It's true that history is by no means static. It may very well be, for example, that performance of funds has improved tremendously relative to the market since the last year covered in the studies with which I am familiar, but these are matters to be determined by factual inquiry, not by supposition, and I must say that I feel very strongly about this notion that you shouldn't try to second-guess.

It's perfectly clear that management has to have responsibility for making a decision as of that time, and no one should take over that responsibility from them. It seems to me equally clear that responsible judgment would dictate that where these management actions are important for the economy as a whole, they should be looked at retrospectively from the point of view of learning something from them.

Now, I'm not sure whether the next point that Mr. Frank made was addressed to me or not. He seemed to be implying, I thought, that I indicated that institutions should perhaps go to the Third Market-

Mr. FRANK: I thought that was what you stated.

DR. FRIEND: Absolutely not!

MR. Frank: I thought you had stated that they possibly should seek other markets. Then I'm incorrect in saying-

Dr. FrIEND: No, I said I believed-and I gather you do alsoin competition between markets.

Now, finally-this is a trivial point-Mr. Frank seemed to take exception to my remark, which was inconsistent with Wall Street lore, that the small investor is a reasonably stable sort of guy and is not too likely to get caught up in the mass hysteria that the more speculative elements of the community frequently get caught up in. $\mathrm{He}$ talked about the fact that we have not had such a period since the early 'thirties. I think it's only fair to point out that the largest oddlot buying balance in history, to my knowledge, took place precisely in the early 'thirties.

Mr. FRANK: They couldn't afford to buy in round lots. 


\section{The Need for More Data About Portfolio Turnover}

Mr. Moses: The differences in point of view between Dr. Friend and me with respect to performance also apply to the significance of portfolio turnover, but it seems to me that what is needed are more adequate studies over longer periods of time and in greater depth. We have done some studies on the effect, or lack of effect, of turnover on our own funds and also on some of our competition. These studies show that if there had been no turnover, everyone would still have done all right; but the portfolio activity improved performance substantially. On the other hand, I suppose there could be some periods where the reverse took place.

Incidentally, the same problem arises with respect to performance. Analyses of performance barely scratch the surface. I would like to see more work in this area.

Portfolio turnover can be affected in many peculiar ways. In 1966 someone else took my place as head of our Research Department, and our turnover increased substantially. And another time we increased our Research Department by 50 per cent, and for some reason our turnover increased substantially. You can draw your own conclusions.

While I have the floor, I want to get back to our performance figures. I nowhere attempted to make any particular correlation between large and small funds. What I merely tried to challenge was the statement in the report that the largest funds did not have the superior performance one would have expected, that they did no better than the average. Most of the evidence I have shows that they did better than the average.

Can I keep the floor for one minute to comment on the question of whether a fund such as Bob Doran's can keep up the high performance it has achieved when it reaches the billion-dollar mark? Let me remind you of the size of Dreyfus Fund and the size of Fidelity Trend. Although I hate to mention competitors, their records support some conclusions that seem contrary to the general impression.

Mr. Brown: I want to follow up on what Bill just said concerning studies that all of us, probably, are making of turnover.

We have found in our own case that the computer is a very useful device for taking the kind of look at ourselves that we were never able to take before, simply because it was such a task.

We have instituted what we call the management audit. The purpose of this management audit is to do somewhat the same thing Dr. Friend had in mind: to look backwards, to check ourselves to 
see if the decisions we're making are correct, and to see if we can discover what factors have caused us to make mistakes.

We have found in a number of cases that the conclusions that we have reached are not necessarily correct. They vary in degree from what we are finding out as we make the very close and detailed examination that the computer permits, but they nevertheless do vary, and I'm sure that there is an opportunity for all of us to learn in this turnover area and in the area of decision-making. I think this will be one place where there will be progress in mutual fund management in the future as a consequence of the availability of electronic data processing equipment.

\section{Relation of Reciprocal Business to Portfolio Turnover}

CoMimissioner WHeat: Bob, I don't have any comment or pertinent observations, except perhaps in one respect.

Obviously, one of the things the SEC has been concerned with is the fact that heavy turnover of portfolios of listed securities does raise a problem that comes from the fact that the turnover of listed securities gives fund managers a vehicle for directed give-ups, cash give-ups, to those who are selling fund shares, as an added incentive to the sale of fund shares.

What concerns us, as we watch these statistics, is whether the turnover has been generated by decisions that the turnover will benefit the fund, whether the turnover results from basically uninfluenced investment decisions, or whether the turnover in part has been influenced by a desire to make available sums of money through the give-up procedure to aid in stimulating fund sales.

We do not as yet have any statistical evidence which would lead us to believe that the rapid increase in fund turnover has been generated to any substantial degree by the problem I mention. But, obviously, it's our job to keep an eye on this. In this respect it's important to note that turnover of over-the-counter stocks does not give the fund managers an opportunity to utilize give-ups, whereas turnover of listed stocks does.

\section{Standards of Performance}

Professor MundHeIM : Listening to all of you, I realize that the turnover problem must ultimately be measured against performance. We have come back to the point touched briefly earlier: what's being done and what can be done to erect some standards so that investors (and regulators) can measure performance in some uniform way, and, thus, make judgments about different fund shares, either from an investing or regulatory point of view? 
Professor BAUM: Before you can measure performance, it may be necessary to look at the basic structure of the mutual fund. Let us asume, that to some extent the high turnover rate is motivated because of the give-ups which can be generated. To the extent that this is true, it might be reasonably necessary to ask-and the report really didn't do this-whether the structure of the mutual fund is such that it has the capacity to yield the best possible performance. Only after you have established a structure that can be efficient will it be possible to look toward the possibility of creating standards or guidelines.

Professor Mundheim: Irwin, do you have a comment on the possibility of erecting usable standards for measuring performance?

DR. FRIEND: In my earlier comments I indicated the nature of my own bias, which is to try to handle this through disclosure. It is so difficult to set up standards which would not interfere with legitimate management prerogatives, that I would much prefer to see an attempt made to handle this through disclosure mechanisms. The obvious one is to have a little box that shows the turnover of the fund in question, properly adjusted for net inflow, vis-à-vis other funds and the market as a whole. Also, if the Commission considers this to be a significant enough problem-and I am beginning to think it is-it might require use of a standard form which, while minimizing the work involved, would give an indication of what performance would have been had the securities sold been held, vis-à-vis the actual performance attained.

I think that I would not go any farther than this.

Professor MundHeIM: I guess that's far enough for some people.

Mr. Brown: Bob, how do you really construct standards of performance that will be meaningful when the final answer to an investment in a mutual fund is whether or not that fund has done what the investor wanted it to do for him?

You can get all kinds of classifications of funds, develop all kinds of standards, and still not have provided the individual investor with the answer. Unfortunately, when we get into this performance question, the bias is in the direction of capital gains. I don't think the mutual fund industry-and I'm talking about the entire industryis exclusively in, let's say, the horse racing business. Many of us are really trying to run what some might call a livery stable. We are trying to provide financial services, and to invest for people as they desire over a period of years. The needs of the individual investor, his temperament, his ability to take risks, his desires, his objectives, 
count very heavily in judging whether a fund has performed well for him and met his needs. And, furthermore, the length of time that an investor holds his shares is a very important consideration from his point of view in measuring performance.

I think that if we reach a point where we have set global standards determined by the SEC or somebody else, and every investor is regimented into making up his mind according to what's supposed to be good for him, we are going to find that a lot of investors have been misguided by the standards and have taken on investments which they should not have. For example, I am still old-fashioned enough to believe, the so-called performance funds notwithstanding, that gain distributions are not a proper substitute for income dividends for the investor who needs income.

Professor BAUM: You talk about investors in terms of what they want. This raises a whole series of questions in terms of the kinds of people being attracted to mutual funds; it forces comment on the selling technique used by funds.

Without getting involved in any lengthy discussion, I have serious reservations about the kinds of people that we are attracting to funds, whether they should be sought out in the first instance, whether it's in the best interests of some to go into a fund, and whether they are in a position to judge whether it's in their best interests. I suppose I would make reference to the contractual plan.

Professor Mundentm: Let me assure you that we are going to discuss that at length on Friday-all day-and we'll be able to get into the merits of that. I would like to stay away for the time being from the merits of that very important question.

Mr. Brown: But leaving aside the contractual plan, what's the record of the people who have invested in mutual funds over a period of years? Have they done badly? Have they had some measure of protection against inflation? Have they received the benefits that the funds offered?

It seems to me perfectly clear that they have.

Now, as to how good this record is, that is something else again. You can argue about that as long as you want to-forever, really-but I think it's very difficult to demonstrate that people who have bought funds on the right basis-and I grant you there are many who have not-in most instances have done better than they would have done had they tried to invest for themselves.

Professor Mundereim: Can I read a question from the floor at this point? "Dr. Friend, should not performance comparisons be 
made between the fund and what an average individual investor has done or could do?"

DR. FRIEND: I think it is a fact that the type of comparison that we did make in the Wharton Study, between the funds and the market as a whole, and the comparison which we did not make because the data were not available, between the performance of funds and that of actual individual investors are both appropriate.

Now, we could not make the second type of comparison, and it's a legitimate question to ask: What would we be likely to have found if we could have made it?

Since the Wharton Study, I have carried out two studies in collaboration with colleagues of mine here at the University, and we studied the performance of investors in different income groups for a limited period of time.

It's perfectly clear that all income groups combined must essentially do the same as the market as a whole, because they constitute the market as a whole. So the real question is: do you get significant differences between the performance of relatively low-income investors, who are more likely to go into mutual funds, and the performance of the higher-income investors?

The tentative answer in those two studies, which are both published in the Proceedings of the American Statistical Association, is that there is absolutely no evidence that the low-income investors do any worse than the upper-income investors. ${ }^{44}$

Just so I don't leave you on that unhappy note, I do think that the mutual fund industry has been very beneficial to low-income investors, since many of them would obviously not have gone into the stock market at all. It is also true that those who would have gone in directly would not have achieved the same degree of diversification that they get through the mutual funds. So that, though on the average individual investors would have done fully as well, they would have had a much bigger dispersion around the same average result, with unfortunate consequences for a significant group of investors.

\section{Impact of the Funds Attracting New Equity Capital}

MR. WEEDEN : I noted that somebody said there was $\$ 40$ billion of new money that had come into the market because of mutual funds. I just wanted to raise the question whether that was all new money which would not have been invested in stocks by individuals if they hadn't gone into mutual funds.

44 Friend \& de Cani, Stock Market Experience of Different Investor Groups, American Statistrcal Association 1966 Proceedings of the Business and EcoNOMIC STATISTICS SECTON 44; Friend \& Crocket, Characteristics of Stock Ozenership, 1963 id. 146. 
If this is all money that would not have gone into the stock market, then you have done a great service to the American people, because you encouraged them to save their money. On the other hand, if this is money that would have gone into the stock market through the judgment of the individuals, counseled by members of the stock exchanges, then you have changed the character of the market. Instead of having a broad market with thousands and thousands of individuals guided by brokers, buying and selling in an auction market, you have concentrated this capital into professional management-in large amounts-and you have developed a necessity for a different technique of market handling.

I don't think that the auction market is able to handle very large blocs purely on an auction basis; but they have supplemented that by a negotiated technique related to the auction market, and we in the Third Market have supplemented it with another type of negotiated technique which must also be related to the prices set by the auction market.

I don't think all this $\$ 40$ billion is new money. I think occasionally mutual fund salesmen go to somebody who has 50 shares of General Motors, and say: Look, if the automobile business goes bad, you're going to lose everything you've got. Now, why don't you sell that and get into a well-managed, professionally-handled security, and you will do better in the long run?

And I'm not here to say that they wouldn't. They probably would. But then that 50 shares of General Motors stock is gradually accumulated by a mutual fund, and we are limiting the number of individuals guided by their brokers. I think, actually, as far as the brokers selling mutual funds are concerned, they are gradually getting themselves out of business in some respects, and they might make more money in the long run doing more business with individuals, instead of trying to get their individual customers into mutual funds.

I did want to point out that it was probably not all new money that went into the mutual funds.

Dr. Friend, as usual, probably has the figures.

Dr. FRIEND: We do have some relevant data, going back, in this case, to the early 'sixties, but I have forgotten the exact proportion. $\mathrm{My}$ recollection is that something around a half of the money probably would not have gone into the market alternatively. This is, incidentally, based on a survey of mutual fund customers. ${ }^{45}$

Now, I'm not sure that all of the half which seems to have represented diversion from normal brokerage can be considered to have 
hurt the brokerage business, because a lot of people also indicated that as a result of getting interested in the securities market through a mutual fund, they not only bought the mutual fund but also bought other stock. So it's rather misleading to use this half-half apportionment for that particular purpose.

But as to the most fundamental point raised-whether the rapid growth in mutual funds will result in so narrow a market as to diminish some of its most desirable properties-I think in certain respects this will happen, but in other respects there will be very significant offsets.

As indicated in my earlier comments, it is far from clear that the market will be a less perfect instrument simply because we have fewer investors, if these investors are better informed.

\section{The Institutional Investor and Inside Information}

Professor Mundheim: Before we close this morning's session, I want to give Fred Brown a chance to deal with a very difficult problem involving institutional investors and their relations with portfolio companies. The report didn't deal with this, but I thought you might, nevertheless, be interested.

The problem relates to the ability of large investors to sit down and talk with corporate officials about the corporation. On the one hand, the effort to dig out as much information about a company as possible is one of the things you buy when you pay for mutual fund management; that is, you hope that they are doing this. On the other hand, the Chairman of the Securities and Exchange Commission in a recent speech before an American Management Association sponsored conference warned that serious questions of law and propriety arise when institutional investors are able to obtain from a company, because of their economic power or for other reasons, information that is not available to other investors. ${ }^{46}$

I suppose the best chart for steering between the Scylla of not digging out enough information and the Charybdis of violating the prohibitions against insider trading would be a precise definition of inside information. I'm not asking you to provide us with that; but perhaps you can suggest some guidelines for governing the conduct of institutional investors in the practice of gathering and using information.

MR. Brown: Ladies and genltemen, I started to leave the hotel room this morning to get the bus and found that I couldn't get the door open. A maid finally let me out.

46 Address by Chairman Cohen, American Management Association, New York, New York, Nov. 16, 1966. 
On the way over in the bus, I read I was supposed to be second on this morning's program. After I got here, Bob informed me that I would be last.

Now he has given you a description of what I will talk about that is a little different from what I prepared. There are bound to be days like this, I guess.

I would like to talk about a bogeyman of the mutual fund business that won't go away. I want to try to get before you a facet of what those who worry and write about mutual funds like to call "The Problem of Size." This is the presumed power of mutual funds to extract inside information, or confidential information, from corporations whose securities they own; and, to complete the thought of those who worry about us, the presumed power of mutual funds to take investment action on the basis of this information, thus gaining an unfair advantage over other investors.

Before this program started this morning, Bob suggested that each of us start by telling two jokes and singing a song. I'm not going to do either. But if I did have to have a theme song, I think it would be the song from "Porgy and Bess" with that line: "They tell all the chillun the Devil's a villain, but it ain't necessarily so."

My subject, it seems to me, is more than a little like that old question: "When did you stop beating your wife?" Do mutual funds have the power ascribed to them? Has it been used? Has it been abused?

My answer to these questions is: for the most part, no. We have problems aplenty, but control over portfolio companies really is not one of them. Those concerned with solutions to the problems of mutual funds might profitably, as I suggested earlier today, spend more time on whether and to what extent the problems do in fact exist. And, let me add that if I am wrong, the problems apply to all institutional investors, not to mutual funds alone. In fact, they may be more serious for some of the other institutions than they are for mutual funds. But, in any event, mutual funds should not be flayed with problems, real or presumed, simply because the funds happen to be subject to greater regulatory control than most other institutional investors.

\section{The Problem of Acquiring Information}

I read an editorial the other day in a widely-circulated financial magazine, and in it there was this line: "The necessity for top corporate management to dance attendance on visitors from funds holding large hunks of the corporation's securities is certainly understandable- 
but damned disturbing." This came as a surprise and a disappointment to my associates and me. We were surprised because we didn't know the necessity existed. We were disappointed because we haven't had the good fortune of late to encounter any dancing executives. This editorial comment, lacking factual basis, is somewhat typical of the statements which the power subject seems to generate too often.

Dan Baum and his co-author, Mr. Stiles, in their book, The Silent Partners, have this to say:

"Inside information, the hint of things to come, becomes a valued commodity to the institutions under constant pressure to make productive use of the monies entrusted to them.

The ability to obtain such confidences is a characteristic in which many institutions take pride; it demonstrates their ability to perform. The basic unfairness to the rest of the investing public is manifest when institutions exercise their power to obtain what is essentially inside information and use that information to change their investment position." ${ }^{47}$

Dan said a little earlier this morning that we advertise this ability to obtain confidences. ${ }^{48}$ This threw me. I have never seen such a claim on a tombstone ad of the type to which mutual funds are restricted.

The Baum-Stiles statement seems to me to be quite a serious charge, if it is true. But I say to you now, as I did last night at dinner to Dan, this charge is not backed up by a single example of a mutual fund having forced a portfolio company to reveal inside, or confidential, information and having either used it or misused it. This is true in his book, and it is also true of every writing that I have ever seen on this power subject.

I think there is a reason why this is so-and I'm not about to claim that no mutual fund has ever gotten hold of any inside, or confidential, information and used it to advantage. I am sure this has happened. The fact is, however, that the amount of inside information that mutual funds can get by any means is grossly over-rated. The fact is that the usefulness of inside information, even if we can get it, is grossly over-rated.

More often than not our problem is to get past the corporate financial relations people, who dispense the party line, so to speak, and in to talk with top corporate management. When we succeed, it usually is a waste of valuable time to pry for confidences. Our purposes are much better served if we find out about plans and problems,

47 BAUM \& STrLes, supra note 8 , at 36-37.

48 See p. 681 supra. 
if we can get grounding in the basics of the business and the factors that influence them, if we can learn about competitive position and forces, and if we can come away with some appraisal of and conviction as to management's ability and the likelihood of its doing a good job. These are the things on which sound investment decisions are based.

To be sure, we would like to get sales and earnings estimates, and commitments on dividend policies. But if we are analysts, and not just reporters, information of that type is taken for our guidance and not as gospel.

\section{The Problem of Evaluating Information}

If we get inside information, our problem then is how to evaluate it. If it's an earnings estimate, is the source chronically optimistic or chronically pessimistic? How will the market value it when it becomes generally known? Or, has the market already discounted what we have been told? How many other people know about it? How many people got there before we did?

Here we are dealing with sentiment, emotion and timing in the market place, and believe me, the opportunity for error is great.

If, as Messrs. Baum and Stiles have written, mutual fund managements "demonstrate their ability to perform" by obtaining and relying on inside information, then I simply say that we have picked a really rough road to negotiate. In the early 'thirties, as a young analyst, I managed to obtain detailed information on the monthly sales and earnings of a leading growth company of that time. I thought I had it made. Then as a new product was nearing introduction, the sales of this company's most important established product turned down, and earnings turned down, and pretty sharply, too. What to do about it?

To my everlasting regret, I said: sell. The new product was announced, and the price of the stock soared. The decline in current earnings was announced, and the market ignored it. We had been duped out of a fine investment by inside information and a presumed advantage over other investors. We later repurchased the stock at a considerably higher price-presumably from some less well-informed investors.

Inside information is difficult to handle. I think it's over-rated, both as to the amount we get and its usefulness. It is not a significant factor in the management of mutual funds.

When I thought about saying that, here today, I wondered whether I might be out of touch with what might be going on in the mutual fund industry. So, I checked with a number of friends 
in the mutual fund field, and I didn't find one who regarded inside information as important in his operations. And, I did find one who thought it more of a hindrance than a help.

\section{The Ethical Problem}

There is, I think, a higher level of ethics in this general area of information gathering than might have been the case in earlier years. Most managers, I think, would agree that access to privileged information tends to tie their hands. I think we have an awareness of the interest of regulators, as referred to by Bob, in this whole area. I think this interest has a prophylactic effect on us, and makes us very conscious that if we get involved in the area, we had better be careful. The pitfalls and entanglements are obvious, and, as a practical matter, they loom large in relation to advantages that might be gained by the use of inside information.

Many mutual funds, like other investing institutions, devote much time and effort to field work: interviewing portfolio company managements, competitors, bankers, suppliers, customers and anyone else who might be a source of information helpful to a profitable investment decision. We stress this work. Dan Baum has said that we advertise it, and, in a sense, maybe we do. He goes on, however, to say that we seek and advertise that we get inside information. There he is wrong. We seek basic information, both general and specific, that bears on investment values. We try to do our jobs well, but we rely on experience and diligence and not on unfair advantage over other investors. This seems obvious on the record, and the SEC seems to have seen it that way. But, the bogeyman of power and control doesn't go away.

Looked at strictly from the standpoint of possible regulatory implications, I would agree that problems exist if, through their field work, funds are able to obtain from corporate management and act to their advantage on information of immediate or shorter-term significance that can be expected, when made public, to have a reasonably predictable effect on the market price of a security. The Cady, Roberts ${ }^{49}$ case and that of a well-known mining company ${ }^{50}$ currently in the news, provide examples. However, neither of these cases involves a mutual fund, nor have any others of which I am aware.

I certainly think that corporate management has an obligation to all stockholders not to disclose sensitive short-term information of this nature, and I don't think, by and large, that those of us who go out and talk with corporate management should try to do too much

49 Cady, Roberts \& Co., 40 S.E.C. 907 (1961).

50 SEC v. Texas Gulf Sulphur Co., 258 F. Supp. 262 (S.D.N.Y. 1966). 
digging or too much trapping for it. We don't need it to operate mutual funds successfully. As a practical matter, we should avoid it in order to avoid getting involved and tied down by it, and losing our freedom to take action in the best interests of our portfolios and our shareholders.

Perhaps other investing institutions have more problems in the area of sensitive information than we in the mutual funds. Take, for example, the case of a bank which has a large trust department, handles many pension funds and the like, and which also is a large lender of money to corporations. I haven't yet figured out whether there is an "iron curtain" between the loan department and the trust department that prevents some, let's say, cross-fertilization of information. But I do think that exposure to problems of inside information is much greater than in the institutional sector limited to mutual funds alone.

Looking to the future, I don't think that we in the mutual fund business have any real problem when it comes to gathering information. It seems to me that we work very hard to try to find out all we reasonably can about a company in which we are apt to invest or in which we have invested. We are concerned with the intermediate and longer-range future. I'm sure all of us here could give figures, but in the case of the companies with which I am associated, we have a nice little statistic which says that we interview ten different managements, or hold ten management interviews, on the average, each working day during the year.

This is a lot of management contacts. I'll admit that we have exercised some power over the years, through our portfolio holdings, in an effort to find out things which we think we reasonably can be told which will influence the long-term position of companies and the market action of their stocks. The value of such information to us, or to any fund management, however, depends on an ability to evaluate it. We don't ask for information on a private or restricted basis. If such information means more to mutual fund managers, or if they can put it to more effective use because of their experience and continuing analytical work, they can hardly be said to be taking unfair advantage of other investors.

But what has been the result of our efforts to secure information? It seems to me to be perfectly obvious that through our efforts and the efforts of other institutions, in general, the information made available to the investing public has greatly improved. Investors have become more sensible and sophisticated and the efficiency of the securities markets in directing the flow of capital to where it is needed and 
justified, has improved. Mutual funds are a strong force, even to the extent that they may exercise power, in working in the direction of fuller disclosure, and their interests, therefore, to a considerable degree parallel those of the regulators. If all of this has helped to influence security prices, corporations, in turn, have been forced to keep investors better informed.

\section{The Special Problem of the Conglomerates}

Having said all of this, I do think there is a somewhat new area in the mutual fund field where perhaps this question of inside information is a little more ticklish. I have in mind the conglomerate corporation which was referred to earlier this morning and now has entered our industry. I don't have in mind any suggestions for regulation. On the contrary, I suspect that these conglomerate corporations are very conscious of the possibility that they might secure information from a competitor company that should not ordinarily come to them, and I suspect they are very, very careful in this area.

\section{The Need To Further Define the Problems}

Perhaps there are regulatory problems and implications in the mutual fund business that I don't know about or haven't recognized. However, I don't see the presumed and imagined problems of power and control over portfolio companies to be real problems. Ask corporate executives if mutual funds control them-they are more likely to agree that we pester them. And so, I agree with the SEC that there is no need for new legislation to curb such power and control. I think, as I said at the outset, that if the mutual fund industry has problems, the problems themselves must be defined before the cure for them is decided upon. We welcome the scrutiny of academicians and others, but we hope for constructive suggestions for progress. We just can't be left in the middle forever.

Take this issue of control over portfolio managements. On the one hand, when funds say they would rather sell a stock than oppose management, there is the concern that we are abdicating our responsibilities. On the other hand, when we vote "no" on management's proposal, or when we try to influence a management decision, there is concern that we are exerting too much influence.

Take the area of the influence of mutual funds on the liquidity of the securities markets. On the one hand there is concern that growth in the size of mutual funds and other institutional investors may be causing a thinning of securities markets and reducing their liquidity. On the other hand, statistics showing higher turnover for 
mutual funds than for other institutions create concern that there may be too much trading activity by funds, and that they may be unduly influencing short-term fluctuations in the markets.

Take the matter of investment information about which $I$ have talked today. On the one hand, it is sometimes said that mutual funds only buy standard stocks, the inference being that the professional manager is not fully earning his fee and is not giving the kind of investment management which the public has been led to expect of him. On the other hand, as we have discussed, concern is expressed that the fund manager has been doing too good a job, has been throwing his weight around too much, has been getting too much inside information, and has been getting a manifestly unfair advantage over the public.

If there are problems or regulatory implications in the role of mutual funds as investors, they must be defined before they can be solved or settled. If they cannot be defined, then they must be, as I believe, more imaginary than real.

There is great risk in separating us as an industry too much, pulling us too far away from the public. We are part of the public. We represent the public. It is the public's money with which we are dealing.

Free flow of information is needed for intelligent investment decisions. It is as vital to all investors as it is to the mutual funds. It is vital to the efficient functioning of securities markets. But its flow is very sensitive.

The one thing I urge-the one thing I hope-is that neither the professors, nor the regulators, nor anyone else will ever try to close this highway, simply because there might be some bad drivers on it. 